\title{
Een beetje mens vergrijst niet
}

Citation for published version (APA):

Kempen, G. I. J. M. (2003). Een beetje mens vergrijst niet. Maastricht University. https://doi.org/10.26481/spe.20031107rk

Document status and date:

Published: 07/11/2003

DOI:

10.26481/spe.20031107rk

Document Version:

Publisher's PDF, also known as Version of record

\section{Please check the document version of this publication:}

- A submitted manuscript is the version of the article upon submission and before peer-review. There can be important differences between the submitted version and the official published version of record.

People interested in the research are advised to contact the author for the final version of the publication, or visit the DOI to the publisher's website.

- The final author version and the galley proof are versions of the publication after peer review.

- The final published version features the final layout of the paper including the volume, issue and page numbers.

Link to publication

\footnotetext{
General rights rights.

- You may freely distribute the URL identifying the publication in the public portal. please follow below link for the End User Agreement:

www.umlib.nl/taverne-license

Take down policy

If you believe that this document breaches copyright please contact us at:

repository@maastrichtuniversity.nl

providing details and we will investigate your claim.
}

Copyright and moral rights for the publications made accessible in the public portal are retained by the authors and/or other copyright owners and it is a condition of accessing publications that users recognise and abide by the legal requirements associated with these

- Users may download and print one copy of any publication from the public portal for the purpose of private study or research.

- You may not further distribute the material or use it for any profit-making activity or commercial gain

If the publication is distributed under the terms of Article $25 \mathrm{fa}$ of the Dutch Copyright Act, indicated by the "Taverne" license above, 


\section{Oratie \\ Universiteit Maastricht}

\section{G.I.J.M. Kempen}

\section{Een beetje mens vergrijst niet}

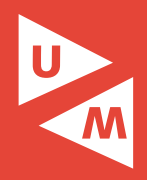




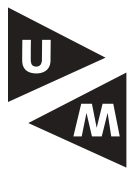

Oratie

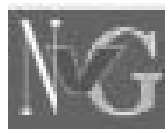

\section{Een beetje mens vergrijst niet}

\section{G.I.J.M. Kempen}

Minisymposium Sociale Gerontologie
R. Sanderman
D.J.H. Deeg
B.W.J.H. Penninx
G.A.M. van den Bos 


\section{Colofon}

Basisontwerp en realisatie: Unigraphic, Universiteit Maastricht

(c) G.I.J.M. Kempen, 2003

ISBN 90-9017-254-8

De leerstoel Sociale Gerontologie is ingesteld door de Nederlandse Vereniging voor Gerontologie per 1 december 2002

Titel van inaugurele rede 'Een beetje mens vergrijst niet' naar Loesje

Druk: Unigraphic, Maastricht

Alle rechten voorbehouden. Niets uit deze uitgave mag worden verveelvoudigd, opgeslagen in een geautomatiseerd gegevensbestand of openbaar gemaakt zonder voorafgaande schriftelijke toestemming van de auteur of uitgever. 


\section{Een beetje mens vergrijst niet ${ }^{1}$}

\section{Openbare rede}

uitgesproken bij de aanvaarding van het ambt van bijzonder hoogleraar Sociale Gerontologie aan de Universiteit Maastricht op vrijdag 7 november 2003

door

\section{dr. G.I.J.M. Kempen}

en vier bijdragen in het kader van het minisymposium Sociale Gerontologie

1 Opgedragen aan mijn moeder in haar geslaagde poging succesvol oud te worden

U

\section{MU Universiteit Maastricht}




\section{Inhoudsopgave}

\section{Prof.dr. G.I.J.M. Kempen, Universiteit Maastricht}

Een beetje mens vergrijst niet

1. Inleiding

2. Van pathologie naar beperkingen in dagelijks functioneren en kwaliteit van leven: het proces van disablement

3. De rol van verzachtende en versterkende factoren in disablement

4. Een voorbeeld: functioneel herstel na valincident met letsel 16

5. Mogelijkheden voor interventie 17

6. Toekomstig onderzoek 20

7. Onderwijs 22

8. Tot slot 23

9. Dankwoord 24

10. Referenties 26

Vier bijdragen aan het minisymposium Sociale Gerontologie

op 7 november 2003 georganiseerd door de divisie Autonomy and Participation van het Care and Public Health Research Institute (CAPHRI) van de Universiteit Maastricht

Prof.dr. R. Sanderman, Rijksuniversiteit Groningen

Psychosociale interventies bij mensen met een chronisch

somatische aandoening: over rationale, evidentie en noodzaak

Prof.dr. D.J.H. Deeg, Vrije Universiteit Amsterdam

Sekse-verschillen in de relatie tussen ervaren gezondheid en sterfte

Dr. B.W.J.H. Penninx, Wake Forest University, USA

De lichamelijke gevolgen van depressie: te verklaren met biologie?

Prof.dr. G.A.M. van den Bos, AMC/Universiteit van Amsterdam/RIVM

Chronisch zieken: ongelijke zorgen, gelijke zorg? 
Mijnheer de Rector Magnificus,

beste collega's, vrienden en familie,

\section{Inleiding}

"De dag brak aan dat de eskimo, misschien niet ouder dan vijftig maar nutteloos bevonden, door zijn kinderen werd achtergelaten op een wegdrijvende ijsschots in het poolwater. Hij had een deken gekregen en wat te eten, maar hij wist dat de schots naar het zuiden dreef en bij de eerste zon zou smelten. De eskimo had zich bij de traditie neergelegd; jaren geleden had hij zijn eigen ouders in de rivier gezet. Misschien hoorde hij in de verte, terwijl de kou in zijn botten neerdaalde, het gegrinnik van het nageslacht. Hij krulde zich op en wachtte tot hij zonk" [1].

"Tienduizenden kilometers naar het zuiden, in de binnenlanden van Zuid-Afrika, was de kans groot dat er ergens een ondervoede oude vrouw als een overbodig vrachtje in een hangmat lag. Haar stam was inmiddels verder getrokken, en zij zou zo misschien nog een dag of zeven blijven hangen, tot ze vervaagd was in een vliegenzwerm. Ze berustte; het was zo de gewoonte bij de Bantoenegers. Ze was niets meer dan afval" [1].

Tot zover deze citaten. In tegenstelling tot wat soms wel eens wordt gedacht, is de hardheid waarmee ouderen in onze verzorgings- en verpleegtehuizen tot hoopjes ellende worden gereduceerd, geen uitwas die is voorbehouden aan een harteloos westers systeem. Zeker in samenlevingen waar schaarste heerst, zijn zorgbehoevende ouderen overbodig en wil men - zoals in genoemde citaten - zich zo snel mogelijk van hen ontdoen. Kortom, in een beschaafde samenleving doen we dat anders. Zonder nu de schrijnende situaties in onze verzorgings- en verpleegtehuizen te bagatelliseren, is het soms toch zinvol te relativeren.

Dames en heren, ik wil vandaag van de gelegenheid gebruik maken om een beeld dat mogelijk bij u bestaat over een doemscenario waar het gaat om de komende grijze golf wat te nuanceren en ook te relativeren.

Nederland vergrijst. Zowat dagelijks bereiken ons berichten hierover via de krant, de radio of de TV. Als ik eerstejaars studenten tijdens een college echter vraag welk deel van de Nederlandse bevolking op dit moment 65 jaar of ouder is, dan blijven de meeste het antwoord schuldig. 
Dit geldt nog in veel sterkere mate voor de vraag welk deel van de bevolking 65 jaar of ouder zal zijn als zijzelf deze pensioengerechtigde leeftijd zullen bereiken, dus over zo'n 40 jaar. De antwoorden zijn makkelijk op te zoeken.

Was in 1950 nog maar $7,7 \%$ van de Nederlandse bevolking 65 jaar of ouder, in 2002 was dit percentage gestegen tot 13,7\% [2]. De verwachting is dat het percentage 65-plussers in Nederland in 2040 verder zal zijn gestegen tot $23,4 \%$ om daarna vervolgens licht te dalen tot $22,3 \%$ in 2050 [3]. Maar is deze ontwikkeling werkelijk zo dramatisch? Voordat ik hier verder op inga wil ik graag met $u$ een testje doen om uw globale kennis op het terrein van de gerontologie vast te stellen. Ik zal u zo enkele stellingen voorleggen en u verzoeken uw hand op te steken als $u$ het met de betreffende stelling eens bent:

De eerste stelling luidt: "In het jaar 2000 behoorde Nederland van alle EU landen tot de TOP 5 met de meeste 65 -plussers". Wie van $u$ is het hiermee eens? Nee! Na lerland - 11,3\% 65-plussers in 2000 - had Nederland zelfs het minste aantal 65 -plussers $(13,7 \%)$ in 2000. Italië scoorde het hoogste met bijna een op de vijf 65-plussers $(18,1 \%)$ [4]. Corresponderend hiermee geeft Nederland - na lerland - ook relatief het minste uit aan pensioenen; in 1998 was dat $6,2 \%$ van het bruto nationaal product [4].

De tweede stelling die ik u wil voorleggen luidt: "In vergelijking met andere Europese landen en de VS zal het aantal ouderen in Nederland in de komende decennia wel veel sneller toenemen". Wie van $u$ is het hiermee eens? Ook dat blijkt niet het geval. Er zijn tal van landen waarvan wordt verwacht dat de proportie ouderen veel sterker zal oplopen dan in Nederland. Terwijl in Tsjechië, Spanje en Italië, de proportie personen van 60 jaar en ouder zal zijn opgelopen tot boven de $40 \%$ in 2050, blijft Nederland volgens verwachting steken op ruim $27 \%[2,5]$.

Is de geschetste ontwikkeling voor wat betreft de grijze golf nu werkelijk zo dramatisch voor Nederland als soms wel wordt beweerd? Er zijn in dit verband tenminste twee redenen waarom ik $u$ de eerder gepresenteerde cijfers heb laten zien. Allereerst: er ontstaat wellicht een probleem omdat we weten dat met het ouder worden gezondheidsproblemen nu eenmaal toenemen, maar we moeten het gezien de internationale context, niet overdrijven. Een argument dat soms hiertegen wordt ingebracht is dat het relatief lage aantal ouderen in Nederland nog niet 
betekent dat er absoluut gezien ook geen probleem is [6], maar met een toekomstige situatie als in Italië of Spanje zouden de omstandigheden naar mijn idee in Nederland toch écht veel nijpender zijn. Er kan mogelijk wel een probleem ontstaan als Ianden als Frankrijk, Italië of Duitsland - waar de vergrijzing veel harder zal toeslaan als in Nederland hun begrotingen niet op orde kunnen krijgen. Dit kan zijn weerslag hebben op Nederland via bijvoorbeeld dwingende Europese regelgeving van deze grote landen of via de stabiliteit van de Euro waardoor Nederland als exportland kan worden getroffen. Een Europese aanpak is vanuit deze optiek dus wel gewenst [7].

Een tweede reden waarom ik $u$ deze cijfers presenteer: we hebben nog heel wat tijd om aan oplossingen te werken. En dat we een neiging hebben om aan oplossingen te werken, blijkt bijvoorbeeld uit het feit dat Nederland in 1998 is gestart met de opbouw van een nationaal spaarfonds AOW als aanvulling op het bestaande pensioenstelsel; vanaf 2020 kunnen we hierop een beroep gaan doen. Vrijwel geen enkel land in Europa is zo in de weer met zijn ouderen als Nederland - terwijl wij nog relatief weinig ouderen hebben ook. Daarnaast kunnen verschillende wetenschappelijke disciplines - waaronder die van de Sociale Gerontologie - hun steentje bijdragen aan het opvangen van de grote grijze golf door de kwaliteit van het leven in de derde levensfase - ondanks mogelijke gezondheidsproblemen - zo optimaal mogelijk te doen laten zijn. Ik hoop u gedurende mijn betoog hierover wat mee te geven.

Redelijk gezond oud worden, kan dat eigenlijk wel? Ja, dat kan. U heeft er wel wat geluk bij nodig en $u$ moet er ook wat voor doen en laten. En soms lukt het niet, omdat het er gewoon niet in zit of omdat $u$ juist geen geluk heeft of omdat u er te weinig voor heeft gedaan. De levensverwachting (dat wil zeggen: de verwachting bij de geboorte hoe oud men zal worden) stijgt. Was de levensverwachting van de Nederlandse man in 1950 nog ongeveer 70 jaar en van de Nederlandse vrouw ongeveer 72,5 jaar, in 2001 zijn deze levensverwachtingen bij geboorte in Nederland gestegen tot respectievelijk bijna 76 jaar voor de man en bijna 81 jaar voor de vrouw [2]. Kijken we naar mensen die de 65 jaar al hebben bereikt, dan komen daar voor de mannen nog ruim 15 jaar bij en voor de vrouwen nog 20 jaar bij [8]. We moeten hierbij wel in ogenschouw nemen dat de zogenaamde gezonde levensverwachting - dat wil zeggen: het aantal jaren dat men verwacht in goede gezondheid te leven - tussen mannen en vrouwen niet veel verschilt. 
Dit betekent dat vrouwen aan het einde van hun leven doorgaans vijf jaar langer met gezondheidsproblemen te kampen krijgen in vergelijking met de mannen [9]. Het verschil in levensverwachting tussen mannen en vrouwen wordt overigens kleiner. Tien jaar geleden was het nog zes jaar, nu is het vijf jaar. De verwachting is dat het in 2040 nog maar drie jaar zal zijn. Vrouwen zijn bijvoorbeeld de slechte mannengewoonten 'roken en drinken' en ook 'betaald werken' gaan overnemen waardoor de toename van hun levensverwachting stagneert [8]. Een jaar geleden heeft het RIVM in Bilthoven echter becijferd dat in vergelijking met de ons omringende landen het met de gezondheid in Nederland minder goed gaat [9]. Onze levensverwachting is weliswaar toegenomen, maar minder snel dan in de meeste andere EU-landen. Het relatief ongezonde gedrag is de belangrijkste oorzaak van deze stagnatie. Er wordt door het RIVM geadviseerd - mede in het licht van de vergrijzing - door een nieuwe, krachtiger preventieaanpak deze trend te beïnvloeden.

Er zijn echter ook andere factoren dan gezondheidsgedragingen die de levensverwachting beïnvloeden. Ons genetisch paspoort (denk aan DNA) bepaalt voor 30 tot 40 procent welke kwalen we krijgen en hoe oud we zullen worden. De overige 60 tot 70 procent hebben we zelf min of meer in de hand [8].

Wilt $u$ zelf graag weten hoe oud $u$ zult worden? Kijk dan op www.beeson.org voor de levensverwachtingtest. Op basis van eerder onderzoek en uw individuele kenmerken wordt een schatting gegeven van uw levensverwachting. Omdat ik hier geen internet bij de hand heb en $u$ toch een indicatie wil geven, laat ik $u$ de volgende gegevens zien, ontleend aan Knook en Ulrich [8]. Als u buiten woont in plaats van in de stad krijgt u vijf jaar extra, datzelfde geldt voor vrouwen in vergelijking met mannen. Gehuwde mannen (+ vier jaar) profiteren wat meer van hun huwelijkse staat in vergelijking met de gehuwde vrouwen (+ twee jaar). De leeftijd van de grootouders speelt - wellicht in genetische zin een rol. Als alle vier uw grootouders minimaal tachtig jaar zijn geworden, krijgt u vier jaar extra. Hetzelfde geldt voor de leeftijd van een van de ouders. Ook hier spelen genetische factoren wellicht een rol. Roken kost mannen zes jaar en vrouwen vijf jaar. Ook vetzucht leidt tot een kortere levensverwachting van zo'n zes tot zeven jaar. Zowel mannen als vrouwen met een hogere sociaal-economische positie, leven circa drie jaar langer. Verder is het heel opmerkelijk dat een positieve levensopvatting substantieel bijdraagt aan een langer leven (+ zeven jaar). 
Daar kom ik straks nog op terug. Ik heb het testje via internet ook zelf gedaan. Zonder nu alle details te verklappen, kwam ik tot een leeftijd van 86,6 jaar; u bent voorlopig nog niet van mij af dus.

Het hoeft natuurlijk geen nader betoog dat met de ouderdom ook de gebreken komen. Een belangrijk deel van deze gebreken heeft betrekking op chronische ziekten die in omvang toenemen. We moeten ons echter wel realiseren dat niet alleen het ouder worden verantwoordelijk is voor veranderende ziektepatronen. Ook de gezondheidszorg zelf - in het bijzonder de snelle toename in medische mogelijkheden - draagt hier in belangrijke mate aan bij. Stierven in 1997 in Nederland nog ruim 14000 personen aan een acuut hartinfarct, in 2001 - dus maar vier jaar later - was dit aantal gezakt tot onder de 12000 [2], mede doordat we door de medische vooruitgang beter in staat zijn een acute aandoening zoals het hartinfarct, adequater het hoofd te bieden. Het aantal gevallen van chronisch hartfalen neemt als gevolg van de betere behandelingsmogelijkheden van het infarct echter wel toe. Dit is een mooi voorbeeld van een verschijnsel dat ook wel wordt aangeduid als de "gezondheidsparadox": door meer en betere medische mogelijkheden ontstaan er ook meer gezondheidsproblemen omdat patiënten de behandeling overleven maar wel restverschijnselen en daarmee veelal blijvende gezondheidsproblemen houden. Dus ook mogelijk een lagere kwaliteit van leven voor degenen die deze acute aandoeningen overleven. Deze ontwikkelingen blijven niet zonder gevolgen. Het accent in de zorg voor bijvoorbeeld patiënten met hartziekten verschuift - weliswaar heel langzaam - van puur medische behandeling naar meer begeleiding, ook in psychisch en sociaal opzicht. Het gaat niet langer alléén om 'de pillen en poeders' (hoe belangrijk die ook zijn), maar ook om de vraag hoe een bedreiging van de kwaliteit van leven kan worden geminimaliseerd.

\section{Van pathologie naar beperkingen in dagelijks functioneren en kwaliteit van leven: het proces van disablement}

In de afgelopen decennia zijn in de wetenschappelijk literatuur verschillende conceptuele schema's ontwikkeld voor het beschrijven van de gevolgen van met name chronische ziekten voor het dagelijks functioneren en de kwaliteit van leven. De International Classification of Impairments, Disability and Handicap - de ICIDH - is met stip de meest bekende [10]. Hierbij wordt verondersteld dat ziekte leidt tot functiestoornissen op orgaanniveau (de zogenaamde impairments), die op hun 
beurt weer leiden tot functiebeperkingen (dat wil zeggen disability) waardoor belemmeringen bij de uitvoering van sociale rollen ontstaan (aangeduid als handicap). De ICIDH is primair ontwikkeld ten behoeve van classificatie van functiestoornissen, functiebeperkingen en handicap. Een belangrijke verdienste van dit denkmodel was dat méér werd gekeken naar de gevolgen van ziekte in plaats van louter naar etiologie, preventie en medische behandeling zoals in het klassieke medisch model gangbaar is. In de loop der jaren is echter ook kritiek gekomen op de oorspronkelijke ICIDH benadering. Allereerst is er van meet af aan onduidelijkheid geweest wat precies met functiestoornissen, functiebeperkingen en handicap werd bedoeld, zodat het nogal lastig was ze in de praktijk van alledag vast te stellen. Het was dus ook nogal problematisch om ze in wetenschappelijk onderzoek te gebruiken; tal van onderzoekers vulden de concepten telkens weer verschillend in met als gevolg de nodige verwarring. Daarnaast - en nog belangrijker - hoeft het zeker niet zo te zijn dat bij verschillende personen dezelfde mate van ziekte of functiestoornissen leiden tot dezelfde mate van functiebeperkingen of handicap zoals de pijltjes in het model ons eigenlijk willen doen geloven. Allereerst zijn er verschillen in relevantie van functieverlies: voor een fervent pianospeler zal reumatoïde artritis een andere impact hebben dan voor iemand die voornamelijk TV kijkt. Daarnaast verschillen individuen in de mate waarin zij mogelijkheden hebben om allerlei hulpbronnen (zoals sociale contacten, persoonlijke vaardigheden, materiële mogelijkheden en dergelijke) in te zetten waardoor de effecten van functiestoornissen op functiebeperkingen kunnen worden verzacht. En andersom: als mensen deze hulpbronnen ontberen kunnen de negatieve effecten van functiestoornissen op functiebeperkingen juist sterker zijn. Een van de eersten die dit hebben onderkend zijn Verbrugge en Jette [11] bij de beschrijving van hun disablement process model in het begin van de jaren negentig. Het model onderscheidt - in navolging van Nagi [12] - ook vier hoofdconcepten in het proces van pathologie naar beperkingen in dagelijks functioneren (de zogenaamde main pathway):

Pathologie $\rightarrow$ functiestoornis $\rightarrow$ functiebeperking $\rightarrow$ beperking in taken/rollen

Pathologie verwijst naar biochemische en fysiologische verstoringen. In medische termen: ziekte of letsel. Functiestoornissen betreffen anatomische, fysiologische, mentale of emotionele afwijkingen, zoals verstoringen en afwijkingen in lichaamsfuncties van bloedsomloop, bewe- 
gingsapparaat of zenuwstelsel; het gaat hier met name om klachten en symptomen. Functiebeperkingen reflecteren restricties in het uitvoeren van voor het dagelijks functioneren noodzakelijke fysieke en mentale handelingen. Zij manifesteren zich op het niveau van het 'organisme als geheel' (denk aan fysieke mobiliteit, zintuiglijk waarnemen, verstaanbaar spreken, cognitieve en emotionele functies zoals korte termijn geheugen, oriëntatie in plaats en tijd, affect etc.). Beperkingen in het uitvoeren van rollen en taken hebben daarentegen betrekking op aan gezondheid gerelateerde moeilijkheden die zich voordoen bij het uitvoeren van activiteiten in het dagelijks leven, zoals het verrichten van verzorgende en huishoudelijke taken en het uitvoeren van werk, hobby's, vrijwilligerswerk en dergelijke. Het onderscheid tussen functiebeperkingen en beperkingen in taken en rollen is gelegen in het feit dat eerstgenoemde beperkingen individuele capaciteiten weerspiegelen die geïsoleerd zijn uit de (sociale en fysieke) omgeving. Beperkingen in taken en rollen worden daarentegen gezien als het vermogen om sociaal gedefinieerde taken en rollen uit te voeren in een specifieke sociaalculturele en fysieke omgeving. Aan de hand van twee voorbeelden kan de betekenis van de vier onderscheiden begrippen worden geïllustreerd: - een vrouw van 74 jaar met osteo-artritis aan beide handen (pathologie) heeft weinig kracht in de handen en stijve vingers (functiestoornis). Hierdoor kan zij bepaalde voorwerpen moeilijk vastpakken (functiebeperking). Koken en schoonmaakwerkzaamheden verlopen moeizaam. De zelfzorgrol komt onder druk (beperkingen in taak/rol);

- een man van 52 jaar met een vergevorderd stadium van longemfyseem (pathologie) voelt zich permanent moe (functiestoornis). Hij kan niet langer dan enkele minuten wandelen en geen traplopen (functiebeperking). Gevolg: hij moet zijn grote hobby tuinieren opgeven (beperking in taak/rol).

Het beschreven model dient te worden opgevat als een proces. Zo kunnen beperkingen in taken en rollen ook weer van invloed zijn op functiebeperkingen, functiestoornissen en pathologie.

\section{De rol van verzachtende en versterkende factoren in disablement}

Het verloop van het disablement process is in de perceptie van Verbrugge en Jette $[11,13]$ niet voor iedere oudere of patiënt identiek. De hoofdconcepten uit de zogenaamde main pathway (van pathologie naar beperkingen in taken en rollen) zijn weliswaar gerelateerd, maar determineren 
elkaar zeker niet volledig. Zo leidt dezelfde pathologie niet altijd tot dezelfde functiestoornissen of functiebeperkingen. Risicofactoren, extra-individuele en intra-individuele factoren kunnen het proces van disablement versnellen dan wel vertragen en kunnen ook de richting ervan sturen.

Risicofactoren zijn vaak al aanwezig voordat het ziekteproces start (denk hierbij aan demografische kenmerken, sociaal-economische positie, bepaalde levensgewoonten op het terrein van roken en alcoholconsumptie voordat pathologie zich manifesteerde, biologische predisposities of genetische factoren). Een aantal hiervan hebben we daarstraks al gezien bij de testgegevens ten aanzien van de levensverwachting. De extra- en intra-individuele factoren spelen een rol als de ziekte reeds zijn intrede heeft gedaan. Ten aanzien van extra-individuele kenmerken kunnen tenminste drie aspecten worden onderscheiden: medische behandeling en revalidatie (bijvoorbeeld chirurgische ingrepen, fysiotherapie, medicatie, voorlichting en arbeidsreïntegratie) kunnen het effect van pathologie op het dagelijks functioneren verzachten. Daarnaast kan worden gedacht aan zogenaamde care voorzieningen: dagelijkse ondersteuning in de vorm van professionele thuiszorg, dagbehandeling, diensten als 'tafeltje dek je' en specifieke hulpmiddelen. Ook aanpassingen of belemmeringen in de fysieke en sociale omgeving van de patiënt (bijvoorbeeld aanpassingen in de woning, op het werk of in het openbaar vervoer) gelden als extra-individuele factoren. Intra-individuele factoren zijn als volgt in te delen: allereerst kan een patiënt of oudere een gedragsverandering gedurende het ziekteproces initiëren (bijvoorbeeld ten aanzien van roken, bewegen, voeding of alcoholconsumptie). Daarnaast kan het (dagelijkse) activiteitenpatroon worden gewijzigd (verandering van tempo, stoppen met bepaalde activiteiten of het vervangen van een activiteit door een andere). Tenslotte kan een heel scala aan psychische en sociale aspecten het proces van disablement beïnvloeden; hierbij kunnen we denken aan cognitieve aanpassing, coping, informele zorg, sociale ondersteuning van de omgeving maar ook aan een specifieke levensopvatting.

De factoren die het disablement process kunnen beïnvloeden zijn verschillend qua beïnvloedbaarheid. Zo zullen sommige risicofactoren (bijvoorbeeld leeftijd) niet of nauwelijks beïnvloedbaar zijn. Andere factoren reflecteren concrete interventies (een medische ingreep, het inschakelen van thuiszorg, het mobiliseren van sociale steun, beïnvloeden van psychisch functioneren, en dergelijke) of beïnvloedbare belemmeringen 
(obstakels in het verkeer, in huis of op het werk). Medisch gerichte interventies kunnen voornamelijk in het linkergedeelte van het model worden gepositioneerd, psychosociaal gerichte interventies of kenmerken op dit terrein meer in het rechtergedeelte van het model. Doordat de risicofactoren en de extra- en intra-individuele kenmerken per patiënt verschillen, zullen gevolgen van chronisch ziek zijn ook per individu verschillen. Het disablement process model geeft zodoende mogelijkheden de individuele uitwerking van de gevolgen van (voornamelijk) chronische ziekten en ook met het ouder worden gepaarde gebreken te begrijpen. Het model biedt tevens aanknopingspunten voor gerichte interventies. Het gehele model is tot op heden nauwelijks empirisch getoetst. Wel worden onderdelen gebruikt als aanknopingspunt voor interventie of onderzoek. Zeer recentelijk hebben we binnen een AIOproject in Maastricht bekeken of de aanwezigheid van depressieve klachten bij ouderen het proces van disablement versnelt [14]. En dat blijkt inderdaad het geval te zijn: bij ouderen met depressieve klachten bleek pathologie sterker samen te gaan met later optredende functiestoornissen en bleken functiebeperkingen eveneens in sterkere mate te leiden tot later optredende beperkingen in taken en rollen; de gegevens hiervoor waren afkomstig van de Longitudinal Aging Study Amsterdam (LASA).

De gedachtengang uit het proces van disablement is ook gebruikt voor de ontwikkeling van een nieuwe International Classification on Functioning, Disability and Health (ICIDH-2 of ICF) [15] waarin ook een duidelijke rol voor externe en persoonlijke factoren in trajecten van functioneren wordt onderkend. Dit model zal ik hier verder niet bespreken.

De invloed van ziekte op dagelijks functioneren varieert dus van individu tot individu en deze variatie neemt eigenlijk alleen maar toe gedurende de levensloop.

Een vraag die direct gekoppeld kan worden aan het proces van disablement en in feite een van de zwaartepunten vormt van deze leerstoel is hoe het nu te verklaren is dat - ongeacht ziekte - sommige personen tot op hogere leeftijd op een acceptabel niveau blijven functioneren terwijl dat bij andere personen veel minder het geval is. Uiteraard spelen biologische predisposities of genetische factoren hierbij een substantiële rol, maar zoals ik al eerder heb aangegeven kan er ook worden gekeken naar andere factoren. 


\section{Een voorbeeld: functioneel herstel na valincident met letsel}

De variabiliteit in functioneren wil ik illustreren aan de hand van onderzoek dat is uitgevoerd naar valproblematiek bij ouderen. Valincidenten komen veel voor bij ouderen. Zo wordt geschat dat tussen de $23 \%$ en $39 \%$ van de zelfstandig wonende ouderen jaarlijks valt; voor de ouderen die verblijven in een verzorgings- of verpleegtehuis zijn deze gegevens vergelijkbaar of zelfs nog iets hoger $[16,17]$. De gevolgen zijn aanzienlijk. Vijf procent van deze "vallers" loopt een fractuur op, bij 1\% van de "vallers" is dat een heupfractuur; en na een heupfractuur overlijdt tussen de 20 en $30 \%$ binnen een jaar [18]. Eveneens $5 \%$ loopt na een val ander letsel op dan een fractuur [17]. De korte en lange termijn consequenties in termen van dagelijks functioneren zijn substantieel [19]. Zo bereikt eenderde tot meer dan tweederde van de "vallers" die letsel oploopt niet meer het oude niveau van voor de val [20-26] en ook de consequenties voor het gebruik van gezondheidszorg zijn groot $[27,28]$. De kosten voor de gezondheidszorg als gevolg van ongevallen van 65 -plussers - en in $80 \%$ van de gevallen gaat het om een valongeval - bedragen in Nederland om en nabij 455 miljoen euro per jaar [29]. Dit is ongeveer $4 \%$ van de totale kosten die de gezondheidszorg aan ouderen besteedt. Omgerekend komt dit neer op 225 euro per jaar per inwoner van 65 jaar of ouder.

Er is in het verleden het nodige onderzoek uitgevoerd naar de risicofactoren voor valincidenten met mogelijk letsel zoals een heupfractuur. Hierbij kan gedacht worden aan verminderde fysieke kracht en evenwichtsgevoel, gebruik van geneesmiddelen, afnemend gezichtsvermogen, cognitieve achteruitgang, moeite met lopen, duizeligheid en restverschijnselen van een beroerte. Onderzoek naar de factoren die een rol spelen bij herstel in functioneren na een val met letsel is echter veel schaarser. Empirisch onderzoek laat zien dat er aanmerkelijke variatie zit in de mate waarin ouderen hun oude niveau van dagelijks functioneren weer bereiken nadat zij zijn gevallen en daarbij een heupfractuur hebben opgelopen. Vanzelfsprekend spelen medische en biologische factoren (inclusief het type fractuur) een belangrijke rol in de variatie van dit functionele herstel. Zo laten verschillende studies zien dat de algehele conditie en de leeftijd van de patiënt alsmede complicaties die al dan niet zijn gerelateerd aan de operatie, het functionele herstel na een heupfractuur beïnvloeden [23,30-35]. Maar ook als deze biomedische factoren in ogenschouw worden genomen en daarvoor wordt gecontro- 
leerd, blijft er opmerkelijk genoeg variatie in functioneel herstel bestaan $[21,36]$. Dit suggereert dat ook andere factoren dan strikt medische - zoals psychische en sociale factoren - een rol van betekenis spelen bij herstel in dagelijks functioneren na een heupfractuur. Hiervoor is ook wel enige empirische ondersteuning $[25,34,35,38,39]$.

Deze bevindingen zijn mede de reden geweest waarom ik ruim tien jaar geleden betrokken raakte bij de opzet en uitvoering van de Groningen Longitudinal Aging Study (GLAS); deze omvangrijke studie was onderdeel van het landelijk stimuleringsprogramma ouderenonderzoek NESTOR. GLAS richt zich op het identificeren van psychosociale factoren die een rol spelen in het dagelijks functioneren van ouderen [40]. Hoewel de aandacht voor dit thema toeneemt, was en is hierover nog relatief weinig bekend. In een van de deelprojecten van GLAS werd de rol onderzocht van psychosociale factoren bij functioneel herstel na een val met letsel bij ouderen; dit letsel kon - in tegenstelling tot het meeste eerdere onderzoek - betrekking hebben op zowel (heup)fracturen als verstuikingen en kneuzingen aan de extremiteiten. Het unieke van dit project - en dus anders dan vrijwel al het eerdere onderzoek - was dat het functioneren zowel vóór de val als drie keer gedurende het jaar na de val in kaart is gebracht; valincidenten en gerelateerd letsel werden opgespoord via een huisartsen signaleringssysteem in de drie noordelijke provincies. Uit de resultaten die in de afgelopen twee jaar beschikbaar zijn gekomen, blijkt dat een substantieel deel van de ouderen - ook met ander valletsel dan een heupfractuur - het oude functionele niveau zoals dat was vóór het letsel - niet meer bereikt [19]; mannen herstellen na een jaar beter dan vrouwen en hetzelfde geldt voor jongere in vergelijking met oudere ouderen [41]. Verder blijkt dat psychosociale kenmerken - zoals gevoelens van controle en competentie, depressieve klachten, mate van emotionele instabiliteit, de mate van ontvangen sociale steun - weliswaar geen overheersende maar toch een significante invloed hebben op het beloop in functioneren na de val [42-45]. Waar het gaat om functioneren en functioneel herstel na valletsel is hier kennelijk nog wat winst te behalen.

\section{Mogelijkheden voor interventie}

De gegevens uit bovenstaande studie zijn mede aanleiding geweest om in het afgelopen jaar samen met de organisaties voor thuiszorg in ZuidLimburg een interventiestudie naar de reductie van valangst bij ouderen 
op te starten. Het gaat hier om een groepscursus die bedoeld is voor zelfstandig wonende ouderen met een zekere angst om te vallen en daaraan gekoppeld activiteiten vermijden. De cursus bestaat uit negen bijeenkomsten waarin de ouderen onder begeleiding van een getrainde verpleegkundige leren valproblematiek en hieraan gekoppelde valangst beter te integreren in hun dagelijkse doen en laten.

Doel van de cursus is om door middel van het verhogen van gevoelens van competentie en controle, die hier toegespitst zijn op vallen, het dagelijks functioneren in fysiek, mentaal en sociaal opzicht te verbeteren. Immers, ervaringen met een val (hetzij van de oudere zelf, hetzij van iemand uit de omgeving) kunnen aanleiding zijn om sociale en fysieke activiteiten uit de weg te gaan waardoor de kans op sociale isolatie en immobiliteit worden verhoogd. We hopen door middel van de cursus de actieradius van ouderen te vergroten. Er wordt bij de cursus gebruik gemaakt van principes uit de sociale leertheorie waarbij aandacht bestaat voor cognitieve herstructurering, probleemoplossing en lichamelijke oefeningen. Het cursusprotocol is afkomstig van een Amerikaanse onderzoeksgroep waarmee wordt samengewerkt [46], maar moest geschikt worden gemaakt voor de Nederlandse context. In het bijbehorende evaluatie-onderzoek wordt nagegaan of het volgen van de cursus positieve effecten heeft op dagelijks functioneren en kwaliteit van leven.

In de medische literatuur wordt naar mijn idee overigens een nogal eenzijdig accent gelegd op de preventie van valpartijen op zich bij ouderen. De vraag rijst tot welke prijs die moeten worden voorkomen als dit ten koste gaat van de actieradius van ouderen in bijvoorbeeld verzorgingsof verpleegtehuizen. De aandacht zou veel meer gericht moeten zijn op een verhoging van de maatschappelijke participatie en de levenskwaliteit ook als het risico van een valincident daarmee toeneemt.

Een ander - eveneens prospectief, observationeel - deelproject uit de Groningen Longitudinal Aging Study betreft het beschrijven en verklaren van dagelijks functioneren van patiënten na het optreden van chronisch hartfalen of een myocard infarct. De eerste resultaten hier laten zien dat psychische factoren - zoals gevoelens van controle en competentie en emotionele instabiliteit - eigenstandig effecten sorteren op toekomstig beloop in mentaal functioneren zoals depressieve klachten en gevoelens van angst [47]. Onder andere deze bevindingen zijn voor de 
Nederlandse Hartstichting en het academisch ziekenhuis Maastricht (azM) aanleiding geweest om een studie naar de evaluatie van een zelfmanagement programma $[48,49]$ bij patiënten met chronisch hartfalen te financieren en door de Universiteit Maastricht te laten uitvoeren; het betreft hier eveneens een groepscursus van zes bijeenkomsten waarin patiënten onder begeleiding van een getrainde verpleegkundige en een hartfalen patiënt wordt geleerd de ziekte een plaats te geven in het leven van alledag. Doel van de cursus is niet zozeer het ziekteproces terug te dringen - want dat is immers een lastige zaak - maar om de negatieve gevolgen van de ziekte voor het alledaags functioneren zoveel mogelijk te beperken en daarmee de levenskwaliteit te verbeteren. Ook in deze cursus wordt gebruik gemaakt van principes uit de sociale leertheorie. Dit project wordt binnenkort samen met Huisartsgeneeskunde van de UM en de afdelingen BZE-VII en Cardiologie van het azM en het Atrium Ziekenhuis in Heerlen gestart. Deze psychosociale zorg kan daarmee onderdeel worden van de gehele zorgketen voor patiënten met hart- en vaatziekten.

In feite vormen deze interventiestudies - waarin we psychosociale kenmerken van ouderen proberen te beïnvloeden - een direct vervolg op het eerdere observationele onderzoek naar de rol die psychosociale factoren spelen in het dagelijks functioneren van ouderen; hieruit kunnen we concluderen dat psychosociale factoren weliswaar geen overheersende maar toch een significante bijdrage leveren. De ontwikkeling en evaluatie van daarop gebaseerde - low-profile - zelfmanagementprogramma's hebben naar mijn idee potentie. Enerzijds omdat zij een positieve weerslag kunnen hebben op ouderen en chronisch zieken en hun dagelijks functioneren; het doet immers recht aan de autonomie van ouderen en chronisch zieken. Het proces van disablement kan hiermee worden beïnvloed. Anderzijds omdat de druk op de gezondheidszorg en de gerelateerde kosten kunnen worden verminderd. Zelfmanagement-programma's vormen mogelijk niet alleen een belangrijke aanvulling op de huidige gangbare zorg aan ouderen en chronisch zieken; zij zorgen mogelijk ook voor een reductie van het gebruik van reguliere zorg.

De invulling van het concept zelfmanagement wil ik hierbij overigens bewust ruim definiëren en ruimer dan in de ziektespecifieke benaderingen gebruikelijk is; het heeft betrekking op het gehele spectrum van disablement. Het gaat immers voor de personen in kwestie niet alleen om het leren hanteren van ziekte- of beperkingengerelateerde symptomen 
en gedrag, zoals bijvoorbeeld het innemen van medicijnen, het volgen van een dieet of andere leefstijladviezen van een hulpverlener. Ook het blijvend kunnen uitvoeren van allerlei dagelijkse activiteiten - verzorgend en huishoudelijk van aard, hobby's, (vrijwilligers)werk en dergelijke - en vooral ook het leren hanteren van emotionele veranderingen als gevolg van ziekte en beperkingen - zoals een veranderend toekomstperspectief, het bijstellen van doelen en dergelijke - zijn cruciaal en behoren onderdeel te zijn van een adequate zelfmanagementaanpak [50]. Deze laatste aspecten zijn niet kenmerkend voor een specifieke ziekte, maar hebben een ziekte-overstijgend karakter. Het is dan ook zeer wel denkbaar dat zelfmanagementprogramma's toepasbaar zijn in groepen waaraan (oudere) personen met verschillende typen aandoeningen deelnemen $[48,49]$.

\section{Toekomstig onderzoek}

Met betrekking tot het onderzoek in de nabije toekomst liggen verschillende terreinen nog braak. Ik noem u vandaag drie onderzoeksthema's die naar mijn idee meer aandacht verdienen.

Het meeste sociaal gerontologisch onderzoek richtte zich tot op heden op de vraag welke factoren van belang zijn voor het dysfunctioneren van ouderen. Er werd en wordt vooral in epidemiologische zin gezocht naar factoren die van belang zijn voor de bedreiging van het functioneren en de kwaliteit van het leven. Op basis van de uitkomsten van dit type onderzoek zijn vervolgens interventies ontwikkeld die moeten bewerkstelligen dat de levensperiode met een acceptabele kwaliteit van leven wordt verlengd; ik heb u eerder enkele voorbeelden geschetst. Het is echter maar zeer de vraag of deze factoren - die dus mede verantwoordelijk zijn voor dysfunctioneren van ouderen - dezelfde zijn als de beschermende factoren die verantwoordelijk zijn voor het feit dat sommigen onder ons tot op hoge leeftijd goed blijven functioneren en anderen juist niet. Dit impliceert dat meer onderzoek nodig is - mede aan de hand van bestaande gegevensbestanden - dat accenten legt op de factoren die een hoge kwaliteit van leven in de toekomst voorspellen in plaats van onderzoek dat gericht is op het opsporen van factoren die mede verantwoordelijk zijn voor toekomstig dysfunctioneren (vergelijk Mackenbach et al. [51]); toekomstige interventies kunnen dan op deze kennis worden gebaseerd. Een mooi voorbeeld hiervan uit het medische onderzoek werd dit jaar gepubliceerd in de Journal of the American 
Medical Association. Eerder epidemiologisch onderzoek leek er op te wijzen dat oestrogenen bescherming zouden bieden tegen het ontstaan van dementie. In een grootschalige interventiestudie bleken echter de voordelen van langdurig toedienen van oestrogenen na de menopauze niet op te wegen tegen de nadelen. Het aantal vrouwen met dementie nam in de interventiegroep significant meer toe dan in de controlegroep waarin een placebo werd gebruikt; het onderzoek werd daarom vroegtijdig stopgezet [52]. Het zou naar mijn idee zo kunnen zijn dat we eerst moeten zoeken naar factoren die bijdragen aan goed cognitief functioneren tot op hoge leeftijd, om vervolgens deze factoren te gebruiken voor het ontwikkelen van interventies ten behoeve van personen die cognitief slecht functioneren. Een vergelijkbare redenering geldt voor andere domeinen van functioneren.

Een tweede thema dat meer aandacht behoeft betreft multi-disciplinariteit. Gerontologie is bij uitstek een multidisciplinaire wetenschappelijke discipline omdat bij het ouder worden zowel het fysiek, sociaal als psychisch functioneren kan worden bedreigd, deze domeinen zijn ook aan elkaar gerelateerd. In de praktijk blijkt het - ondanks vaak goede intenties - niet eenvoudig te zijn meerdere disciplines bij elkaar te brengen en feitelijk te laten samenwerken. Voor wat betreft de eerder geschetste thematiek ligt er een grote uitdaging in het uiteenrafelen van met name biomedische en psychosociale factoren in hun effecten op functioneren en de kwaliteit van leven bij ouderen. In een AIO project dat onlangs met collega's Bosma, Penninx en Van Eijk is opgestart wordt nagegaan in hoeverre sociaal economische positie voorspellend is voor het ontstaan van functionele beperkingen, maar ook welke rol biologische risicofactoren (zoals cholesterol, glucose, verschillende biologische markers) hierin spelen. Dergelijke kennis kan bijdragen aan het verder verfijnen van bruikbare interventies. Voor dit onderzoek wordt gebruik gemaakt van gegevens uit een omvangrijke Amerikaanse studie die thans wordt uitgevoerd: de Health, Aging, and Body Composition Study [o.a. 53].

Een derde thema dat meer aandacht behoeft betreft de verdere uitbouw van de zelfmanagement benadering voor ouderen; deze staat immers pas in de kinderschoenen en behoeft veel meer aandacht in de toekomst. Naast het ontwikkelen van instrumentarium ten behoeve van signalering door professionele hulpverleners van dysfunctioneren, bedreigde levenskwaliteit en valrisico's bij ouderen, is het ook zeer wel 
denkbaar instrumenten te ontwikkelen die ouderen zélf kunnen gebruiken voor het monitoren van hun functioneren en het signaleren van mogelijke problemen; ook dit doet recht aan de autonomie van ouderen. Binnen een netwerk van een aantal Europese onderzoekers wordt ondersteund door een subsidie van de EU - in de komende jaren over de mogelijkheden hiervan nagedacht [54]. Hierbij zou bijzondere aandacht moeten zijn voor doelgroepensegmentatie, dus voor de analyse of bepaalde interventies effectiever zijn in specifieke ouderenpopulaties. Daarnaast is er de uitdaging empirisch na te gaan of zelfmanagementprogramma's ook in ziektegenerieke zin effectief zijn.

$U$ heeft mij vandaag verscheidene keren het concept autonomie horen noemen. Begrippen als competentie, emotionele stabiliteit, gevoelens van controle en dergelijke - die ik ook heb laten vallen - raken hieraan.

Bij autonomie gaat het er om dat ouderen het gevoel hebben dat zij hun leven zelf kunnen inrichten zoals ze dat zouden willen ongeacht de eventuele functionele, situationele, sociale of psychische beperkingen die zij ervaren. Autonomie kan gezien worden als een belangrijke uitkomst van zelfmanagementprogramma's, ook die ik vandaag heb beschreven. Autonomie is echter niet gemakkelijk te meten. Daarom werken we thans in een $\mathrm{AlO}$ project aan een theoretische, een kwalitatieve en een kwantitatieve invulling van het concept autonomie specifiek bij ouderen met een chronische ziekte. Daarmee kan het effect van interventies op dit specifieke concept in de toekomst worden onderzocht.

\section{Onderwijs}

Dan het onderwijs. De bijzondere leerstoel Sociale Gerontologie is gevestigd in de capaciteitsgroep Zorgwetenschappen van de Faculteit der Gezondheidswetenschappen van de Universiteit Maastricht. Het onderwijs binnen de leerstoel is met name daar geconcentreerd. In de nieuwe bachelor opleiding Gezondheidswetenschappen - die momenteel wordt ingevoerd - is vanaf het tweede jaar de major Zorgwetenschappen ingebouwd. Voorts wordt thans de master Health Care Studies ontwikkeld. Studenten wordt in deze opleidingen geleerd op welke wijze problemen in de zorg rondom chronisch zieken en ouderen kunnen worden geïdentificeerd, op welke wijze deze problemen kunnen worden aangepakt, en hoe - het gaat vooral om zorgvernieuwing, zorginterven- 
ties en dergelijke - oplossingen kunnen worden geïmplementeerd, begeleid en geëvalueerd om na te gaan of de gekozen oplossingen wel leiden tot de gewenste effecten. Gerontologische kennis is hierbij onontbeerlijk. Zo komt er in de opleiding ruimschoots aandacht voor demografische ontwikkelingen en de vergrijzing ook in internationaal perspectief, veranderende morbiditeitpatronen en chroniciteit en in het verlengde hiervan de eerder besproken gezondheidsparadox, informele zorg, valproblematiek, de ouderenzorg en zorgvernieuwende activiteiten hierbinnen, de medische en klinische aspecten van de ziektebeelden chronisch hartfalen, artrose, diabetes, ziekte van Alzheimer, kanker en het CVA. Verder zullen stageplaatsen worden gecreëerd binnen het ouderenonderzoek dat nu en in de toekomst binnen het Care and Public Health Research Institute - kortweg CAPHRI - wordt uitgevoerd. De kennis die kan worden gegenereerd uit het zelfmanagement onderzoek is echter ook belangrijk voor artsen en andere professionals in de gezondheidszorg. In het kader van het Maastricht University Center for Health - kortweg MUCH genoemd - waarin de Faculteiten der Geneeskunde en Gezondheidswetenschappen nauwer willen gaan samenwerken met het academisch ziekenhuis Maastricht, kan deze onderwijslijn worden gecontinueerd. Zelfmanagement kan worden geïntroduceerd als onderdeel van de gehele zorgketen voor de (oudere) patiënt met chronische aandoeningen.

\section{Tot slot}

Ik heb vandaag enkele zaken voor het voetlicht gebracht en ik hoop u daarmee iets te hebben meegegeven. Als eerste: er staan ons weliswaar grote veranderingen te wachten, maar het is goed om zo nu en dan ook te relativeren. Vanuit Europees perspectief blijft de vergrijzing in Nederland naar verwachting duidelijk achter. Geen paniek dus. Het gaat naar mijn idee meer om uitdagingen dan om bedreigingen.

Ten tweede: het ijs is nog niet zo snel gesmolten als ik in het begin van mijn betoog heb gemeld. En we willen het niet laten smelten ook! Er is nog geruime tijd te gaan voordat de vergrijzing het toppunt heeft bereikt; er kan dus aan oplossingen worden gewerkt. Uit mijn betoog is hopelijk duidelijk geworden dat de Sociale Gerontologie - zoals die met deze leerstoel zal worden ingevuld - kan bijdragen aan het verlengen van een gezonde levensverwachting en het verkorten van de periode die met een lage kwaliteit van leven wordt doorgebracht; dit wordt ook aangeduid met de term 'compressie van morbiditeit' [9]. Echter, 
zwaardere accenten op de ontwikkeling en implementatie van zelfmanagement bij specifieke groepen ouderen en chronisch zieken zijn niettemin op korte termijn zeer gewenst om op langere termijn de vruchten hiervan te kunnen plukken. Zeker waar het gaat om een ruimere invulling van het concept zelfmanagement - dus niet louter gericht op ziekte - waarover ik eerder over sprak. Het komt tegemoet aan wens voor meer autonomie. Daarnaast biedt de stimulering van zelfmanagement mogelijkheden om de gezondheidszorg te ontlasten of de groei ervan af te remmen. In de context van het proces van disablement kan zelfmanagement de gevolgen van ziekte en functiestoornissen positief beïnvloeden. De overheid wenst ouderen en chronisch zieken onafhankelijk te laten zijn van voorzieningen, maar dan moet er op dit punt wel visie en beleid worden ontwikkeld; dat lijkt bij het huidige kabinet niet het geval.

\section{Dankwoord}

Dames en heren, ik ben nu aan het einde gekomen van het inhoudelijk deel van mijn betoog. Ervalt nog veel meer te zeggen over het boeiende terrein van de Sociale Gerontologie. De tijd dwingt mij echter om me te beperken.

Ik wil afsluiten met enkele woorden van dank. Het Bestuur van de Nederlandse Vereniging voor Gerontologie heeft deze bijzondere leerstoel Sociale Gerontologie aan de Universiteit Maastricht ingesteld en mij benoemd als leerstoelhouder. Een belangrijk doel van deze vereniging is de gerontologie in Nederland te stimuleren, onder andere door het toekennen van prijzen voor scripties en proefschriften, het medeorganiseren van het nationale congres gerontologie en het instellen van leerstoelen [55]. De instelling van deze leerstoel en mijn benoeming werden ondersteund door het College van Bestuur en het Bestuur van de Faculteit der Gezondheidswetenschappen in Maastricht. Met name de hoogleraren Dick Sipsma - bestuursvoorzitter van de Nederlandse Vereniging voor Gerontologie - en Cor Spreeuwenberg - decaan van de Faculteit der Gezondheidswetenschappen in Maastricht - wil ik danken voor het in mij gestelde vertrouwen. Mijn sociaal gerontologische wortels liggen bij het Noordelijk Centrum voor Gezondheidsvraagstukken van de Rijksuniversiteit Groningen. Mijn oud-collega's aldaar, en in het bijzonder de hoogleraren Theo Suurmeijer, Wim van den Heuvel, Hans Ormel en Robbert Sanderman, wil ik bedanken voor de ruimte die ik daar tot mijn overgang naar Maastricht in 1998 heb gekregen. Met mijn collega's van de sectie Medische Sociologie in Maastricht heb ik in de 
afgelopen jaren heel prettig samengewerkt. Dit geldt ook voor een heel aantal medewerkers van de Capaciteitsgroep Zorgwetenschappen, met name waar het gaat om de opleiding Zorgwetenschappen. Ook hen wil ik bedanken voor de prettige samenwerking. Mijn onderzoek is ingebed in het Maastricht Care and Public Health Research Institute (CAPHRI), met name in de divisie Autonomie en Participatie die onder leiding staat van professor Jacques van Eijk. Ook daar heb ik in de afgelopen jaren vruchtbaar kunnen samenwerken met tal van mensen en mijn onderzoek verder vorm kunnen geven. Ik wil deze rede opdragen aan mijn moeder. Ik zie in haar een voorbeeld van hoe men succesvol oud kan worden. En dan Anita: als jij ruim vijf jaar geleden niet bereid was geweest te verhuizen van het hoge noorden naar het diepe zuiden, had ik hier nu niet gestaan. Ik dank je voor je onuitputtelijke steun.

Ik heb gezegd! 


\section{Referenties}

1. Moor M de. Oud en onafhankelijk. HP/De Tijd, week 20; pp 27-36, 2003.

2. CBS Statline (staline.cbs.nl). Voorburg/Heerlen, 2002, 2003.

3. Nationaal Kompas Volksgezondheid. RIVM, Bilthoven, 2002.

4. OECD Health Data 2OO2. OECD Health Policy Unit, Paris, France, 2002.

5. World Health Organization. Health and ageing. A discussion paper. Geneva, Switzerland, 2001.

6. Praag BMS van. Overheid moet kindertal bevorderen. De Volkskrant 5 augustus 2003.

7. NRC Handelsblad. Paniek over vergrijzing onnodig. Amsterdam / Rotterdam, 30 juli 2003.

8. Knook D, Ulrich H. De kracht van je leven. Prometheus / NRC Handelsblad, Amsterdam / Rotterdam, 2003.

9. Oers JAM van (eindredactie). Gezondheid op Koers? Volksgezondheid Toekomst Verkenning 2002. RIVM, Bilthoven, 2002.

10. World Health Organization. International Classification of Impairments, Disability and Handicaps. Genèva, 1980.

11. Verbrugge LM, Jette AM. The disablement process. Soc Sci Med 1994; 38: 1-14.

12. Nagi SZ. Disability concepts revisited: implications for prevention. In: Pope AM, Tarlov AR (red.). Disability in America. Towards a national agenda for prevention, pp 309-327. National Academy Press, Washington DC, 1991.

13. Kempen GIJM, Eijk JThM van. Patiënt, autonomie en hulpverlening. In: Aakster CW, Groothoff JW (red.). Medische sociologie, pP 75-83. Wolters-Noordhoff, Groningen/Houten, 2003.

14. Gool CH van, Kempen GIJM, Penninx BWJH, Deeg DJH, Beekman ATF, Eijk JThM van. Impact of depression on disablement in late middle aged and older persons. Results from the Longitudinal Aging Study Amsterdam. Ter publicatie aangeboden.

15. World Health Organization. ICIHD-2. International Classification on Functioning, Disability and Health. Genèva. [te downloaden van www.who.int/icidh], 2000.

16. Ryynänen O, Kivelä S, Honkanen R, Laippala P, Soini P. Incidence of falling injuries leading to medical treatment in the elderly. Public Health 1991; 105: 373-386.

17. Stalenhoef PA, Crebolder HFJM, Knottnerus JA, Van der Horst FGEM. Incidence, risk factors and consequences of falls among elderly subjects living in the cummunity. A criteria-based analysis. Eur J Public Health 1997; 7: 328-334.

18. Forsen L, Sogaard AJ, Meyer HE, Edna T, Kopjar B. Survival after hip fracture: short- and long-term excess mortality according to age and gender. Osteoporos Int 1999; 10: 73-78.

19. Scaf-Klomp W, Sonderen E van, Sanderman R, Ormel J, Kempen GIJM. Recovery of physical function after limb injuries in independent older people living at home. Age Ageing 2001; 30: 213-219. 
20. Cummings SR, Phillips SL, Wheat ME, Black D, Goosby E, Wlodarczyk D, Trafton P Jergesen $\mathrm{H}$, Winograd $\mathrm{CH}$, Hulley SB. Recovery of function after hip fracture: the role of social supports. J Am Geriatr Soc 1988; 36: 801-806.

21. Jette AM, Harris BA, Clearly PD, Campion EW. Functional recovery after hip fracture. Arch Phys Med Rehabil 1987; 68: 735-740.

22. Kitamura S, Hasegawa $Y$, Suzuki S, Sasaki R, Iwata $H$, Wingstrand $H$, Thorngren KG. Functional outcome after hip fracture in Japan. Clin Orthop 1998; 348: 29-36.

23. Koval KJ, Skovron ML, Aharonoff GB, Zuckerman JD. Predictors of functional recovery after hip fracture in the elderly. Clin Orthop 1998; 348: 22-28.

24. Kreutzfeldt J, Haim M, Bach E. Hip fracture among the elderly in a mixed urban and rural population. Age Ageing 1984; 13: 111-119.

25. Magaziner J, Simonsick EM, Kashner M, Hebel JR, Kenzora JE. Predictors of functional recovery one year following hospital discharge for hip fracture: A prospective study. J Gerontol Med Sci 1990; 45: 101-107.

26. Tinetti ME, Baker DI, Gottschalk M, Williams CS, Pollack D, Garrett P, Gill TM, Marottoli RA, Acampora D. Home-based multicomponent rehabilitation program for older persons after hip fracture: a randomized controlled trial. Arch Phys Med Rehabil 1999; 80: 916-922.

27. Madhock R, Green S. Longer term functional outcome and societal implications of upper limb fractures in the elderly. J Royal Soc Health 1993; 113: 179-180.

28. Nankhonya JM, Turnbull CJ, Newton JT. Social and functional impact of minor fractures in elderly people. Br Med J 1991; 303: 1514-1515.

29. ZonMw. Preventie loont. Tussenstand van het Programma Preventie van ZonMw. Deel 2 Ouderen. Van Gorcum, Assen, 2003.

30. Broos PLO, Haaften KIK, Stappaerts KH, Gruwez JA. Hip fractures in the elderly. Mortality, functional results and social re-adaptation. Int Surg 1989; 74: 191-194.

31. Broos PLO, Stappaerts KH, Luiten EJT, Gruwez JA. Home-going: prognostic factors concerning the major goal in treatment of elderly hip fracture patients. Int Surg 1988; 73 : 148-150.

32. El Banna S, Raynal L, Gerebtzof A. Fractures of the hip in the elderly: therapeutic and medico-social considerations. Arch Gerontol Geriatr 1984; 3, 311-319.

33. Fox KM, Hawkes WG, Hebel JR, Felsenthal G, Clark M, Zimmerman SI, Kenzora JE. Mobility after hip fracture predicts health outcomes. J Am Geriatr Soc 1998; 46, 169-173.

34. Mossey JM, Knott K, Craik R. The effects of persistent depressive symptoms on fracture recovery. J Gerontol Med Sci 1990; 45: 163-168.

35. Mossey JM, Mutran E, Knott K, Craik R. Determinants of recovery 12 months after hip fracture: the importance of psychocosocial factors. Am J Public Health 1989; 79: 279-286.

36. Ceder L, Thorngren K, Wallden B. Prognostic indicators and early home rehabilitation in elderly patients with hip fractures. Clin Orthop 1980; 152: 173-184. 
37. Billig N, Ahmed SW, Kenmore PI. Hip fracture, depression, and cognitive impairment: a follow-up study. Orthop Rev 1998; 17: 315-320.

38. Mutran EJ, Reitzes DC, Mossey J, Fernandez ME. Social support, depression, and recovery of walking ability following hip fracture surgery. J Gerontol Soc Sci 1995; 50: 354-361.

39. Young Y, Brant L, German P, Kenzora J, Magaziner J. A longitudinal examination of functional recovery among older people with subcapital hip fractures. J Am Geriatr Soc 1997; 45: 288-294.

40. Kempen GIJM, Brilman El, Ormel J. Groningen Longitudinal Aging Study. Een onderzoek naar het dagelijks functioneren, het welbevinden en de zorgbehoefte van ouderen. Tijdschr Gerontol Geriatr 1998; 29: 141-149.

41. Kempen GIJM, Sanderman R, Scaf-Klomp W, Ormel J. Gender differences in recovery from injuries to the extremities in older persons. A prospective study. Disabil Rehabil 2003; 25: $827-832$.

42. Bosma H, Sanderman R, Scaf-Klomp W, Van Eijk JThM, Ormel J, Kempen GIJM. Demographic, health-related, and psychosocial predictors of changes in depressive symptoms and anxiety in late middle-aged and older persons with fall-related injuries. Psychol Health. In druk.

43. Kempen GIJM, Scaf-Klomp W, Ranchor AV, Sanderman R, Ormel J. Social predictors of recovery in late middle-aged and older persons after injury to the extremities. A prospective study. J Gerontol Soc Sci 2001; 56B: 229-236.

44. Kempen GIJM, Ormel J, Scaf-Klomp W, Sonderen E van, Ranchor AV, Sanderman R. The role of perceived control in the process of older peoples' recovery of physical functions after fall-related injuries. A prospective study. J Gerontol Psy Sci 2003; 58B: 35-41.

45. Kempen GIJM, Sanderman R, Scaf-Klomp W, Ormel J. The role of depressive symptoms in recovery from injuries to the extremities in older persons. A prospective study. Int J Geriatr Psychiatry 2003; 18: 14-22.

46. Tennstedt S, Howland J, Lachman M, Peterson E, Kasten L, Jette A. A. randomized, controlled trial of a group intervention to reduce fear of falling and associated activity restriction in older adults. J Gerontol Psy Sci 1998; 53: 384-392.

47. Jaarsveld CHM van, Ranchor AV, Sanderman R, Ormel J, Kempen GIJM. The role of premorbid psychological resources in short- and long-term adjustment after cardiac disease. A prospective study in the elderly. Ter publicatie aangeboden.

48. Lorig K, Ritter P, Stewart AL, Sobel DS, Brown BW, Bandura A, Gonzalez VM, Laurent DD, Holman HR. Chronic disease self-management program: 2-year health status and health care utilization outcomes. Med Care 2001; 39: 1217-1223.

49. Lorig K, Sobel DS, Stewart AL, Brown BW, Bandura A, Ritter P, Gonzalez VM, Laurent DD, Holman HR. Evidence suggesting that a chronic disease self-management program can improve health status while reducing hospitalization. Med Care 1999; 37: 5-14.

50. Lorig K, Holman H, Sobel D, Laurent D, Gonzalez V, Minor M. Living a healthy life with chronic conditions ( $2^{\text {nd }}$ edition). Bull Publishing Company, Palo Alto CA, 2000. 
51. Mackenbach JP, Van den Bos J, Joung IM, Mheen $H$ van de, Stronks K. The determinants of excellent health: different from the determinants of ill-health? Int J Epidemiol 1994; 23: $1273-1281$.

52. Shumaker SA, Legault C, Thal L, Wallace RB, Ockene JK, Hendrix SL, Jones BN, Assaf AR, Jackson RD, Moeley-Kotchen J, Wassertheil-Smoller S, Wactawski J. Estrogen plus progestin and the incidence of dementia and mild cognitive impairment in postmenopausal women. The women's Health Initiative Memory Study: a randomized controlled trial. JAMA 2003; 289: 2651-2662.

53. Rooks RN, Simonsick EM, Miles T, Newman A, Kritchevsky SB, Schulz R, Harris T. The association of race and socio-economic status with cardiovascular disease indicators among older adults in the Health, Aging, and Body Composition Study. J Gerontol Soc Sci 2002; 57: $247-256$.

54. Www.profane.eu.org

55. Www. nvgerontologie.nl 


\title{
Psychosociale interventies bij mensen met een chronisch somatische aandoening: over rationale, evidentie en noodzaak
}

\author{
Prof. Dr. R. Sanderman \\ Rijksuniversiteit Groningen
}

In deze bijdrage wordt een beschrijving gegeven van te onderscheiden psychosociale interventies, te weten naar moment in het behandelingstraject, doel en type interventie. De nadruk in deze presentatie zal echter liggen op het presenteren van gegevens omtrent de evidentie met betrekking tot de effectiviteit van dergelijke interventies. Daarop aansluitend zal tot slot de toekomst van dit terrein van zorg en onderzoek worden besproken.

Door de vergrijzing is er sprake van een toename van het aantal mensen dat leeft met een (chronisch) somatische aandoening en door de toegenomen effectiviteit van de medische technologie leven mensen langer met de aandoening die ze hebben. Daarbij is overigens opvallend dat in de laatste 10 jaar een ziekte als kanker meer en meer als een chronische ziekte wordt gekenschetst. Er wordt - gelukkig - steeds meer aandacht besteed aan de psychosociale begeleiding van patiënten, zowel in de meer acute als chronische fase $[1,2,3,4]$. In een tijd waarin 'evidencebased' in het medische domein centraal staat, wordt ook ten aanzien van psychosociale interventies bij somatisch zieken de vraag gesteld wat de evidentie is dat deze interventies effectief zijn en met oog op welke uitkomst.

Mensen die geconfronteerd worden met een somatische aandoening en daarmee leven, hebben te maken met veranderingen en aanpassingen op verschillende terreinen. Een onderscheid kan worden gemaakt naar de volgende aspecten: (1) medische (zoals compliance), (2) gedragsveranderingen (bv meer bewegen), (3) rolveranderingen (t.a.v. bijvoorbeeld werk, vrienden en de intieme relatie) en (4) emotionele gevolgen (angst, depressie, zingeving). Ten aanzien van interventies die ingaan op deze onderdelen zien we dat deze worden aangeboden op verschillende niveaus, te weten: (1) in het kader van de standaard zorg (zoals voorlichting om compliance te bevorderen en het geven van steun), (2) als selfmanagement, mogelijk met wat ondersteuning door een professional [1] en (3) als intensievere interventie [4]. In het kader van deze bijdrage gaat het vooral om de laatste twee vormen.

Bij het in beschouwing nemen van de effectiviteit van interventies is het natuurlijk van belang waar we de effecten aan afmeten. In veel inter- 
ventieonderzoek staan beoogde verbeteringen in termen van kwaliteit van leven voorop, zoals het verminderen van depressieve klachten en angst [3]. Maar ook veranderingen in cognities of gedrag behoren nogal eens tot de gewenste uitkomsten, vaak met als doel weer andere uitkomsten te bewerkstelligen. Als secundaire uitkomsten wordt daarnaast gekeken naar besparingen in gezondheidszorgkosten en duur van overleving.

De keuze van interventies wordt natuurlijk ingegeven door medische behandelingsaspecten en de aard van de ziekte. Psychosociale interventies kunnen de medische behandeling ondersteunen en/of een essentieel onderdeel daarvan uitmaken. Ondersteunen door mensen met angst voor bepaalde ingrepen daar in voor te bereiden c.q. bij te staan. Ook worden patiënten behandeld met het oog op het omgaan met de meer langere termijn effecten en het bevorderen van succesvolle adaptatie. Psychosociale interventies worden ook aangeboden omdat niet zelden gedragsverandering als secundair preventief middel essentieel is in het kader van een goede behandeling. In het aanbod zien we meer en meer dat behandelingen bij te onderscheiden aandoeningen overeenkomsten vertonen - ofwel de gevolgen van aandoeningen en de adaptatie aan aandoeningen vertonen veel identieke problemen (ziektegenerieke processen) en vragen dus om meer generieke interventiemodellen. Daarnaast hebben ziekten ook hun eigen ziekte-specifieke klachten en gevolgen die om een meer op de specifieke ziekte gerichte behandeling vragen - eventueel in te passen in de ziekte-generieke aanpak. Zo zijn er natuurlijk verschillen tussen ziekten waarin gedragsveranderingen zeer essentieel zijn (zoals diabetes) terwijl de dreiging om er aan te overlijden veel minder hoog is dan bijvoorbeeld een ziekte als kanker waarbij die dreiging hoog ligt, terwijl het belang van gedragsveranderingen (vaak) minder op de voorgrond staat.

Indien we de literatuur over psychosociale interventies onder de loep nemen is opvallend dat zeer veel studies onder kankerpatiënten zijn uitgevoerd [4]. Gelukkig zien we echter dat in toenemende mate ook gecontroleerde studies bij andere aandoeningen worden gepubliceerd (diabetes, COPD [3], hartfalen, hartinfarct) $[5,6]$. In de presentatie zal aan de hand van een aantal voorbeelden de effectiviteit van een aantal type interventies worden aangetoond. Ingegaan zal worden op self-management [7], interventies gekoppeld aan de directe medische behandeling (zoals kort na een Myocard Infarct) [5,8], partner-relatie ondersteuning bij het omgaan met ziekte [9] en individuele- en groepsinterventies die van invloed zijn op kwaliteit van leven en survival $[5,6,10]$. 
Ik zie voor de toekomst een belangrijke rol weggelegd voor het type interventies welke ik in deze bijdrage bespreek. Van belang voor het verbeteren van de directe medische behandelingen (bv. compliance, gedragsveranderingen), als ook in de meer chronische fase (zoals bestendigen gedragsveranderingen en emotionele verwerking). Het idee dat dit type interventies niet 'evidence-based' is, kan naar het rijk der fabelen worden verwezen. Wat niet wil zeggen dat we er zijn. Gelijk de ontwikkeling van medische technieken valt hier nog veel werk te verrichten. Een probleem is wel dat er weinig middelen zijn voor onderzoek op dit terrein. Veel winst valt te behalen door veel meer te investeren in dit terrein. Inhoudelijk is een interessante ontwikkeling dat er meer aandacht besteed wordt aan motivatie technieken en positieve resources van patiënten. Lang was er weinig verbinding tussen meer motivationeel gericht onderzoek en klassiek cognitief-gedragstherapeutisch onderzoek. Daar lijkt nu een kentering in te komen. We dienen te beseffen dat veel patiënten met een chronisch somatische aandoening, die verwezen worden voor een psychosociale behandeling soms al vele jaren leven met de aandoening waarmee ze worstelen. Het aangeleerde gedrag dat maar moeilijk veranderd kan worden, dateert vaak van ver voor het ontstaan van de aandoening (niet bewegen, alcohol, roken, voeding, omgaan met stress). Daar komt bij dat patiënten bij het omgaan met hun ziekte 'geleerd' hebben dat ze niet in staat zijn zaken ten goede te keren en vergeten wat ze wel aan competentie bezitten. De motivatie valt bovendien soms slecht op te brengen omdat echte verbeteringen er vaak niet in zitten en het vertragen van achteruitgang meestal een belangrijk doel vormt. Mijns inziens kan het beter inpassen van motivatietechnieken en het daaraan te koppelen gebruik maken van positieve resources van patiënten, op korte termijn tot belangrijke stappen voorwaarts leiden [2]. Het valt dan ook te verwachten dat psychosociale interventies in rap tempo aan belang zullen winnen in de medische setting. Innovaties en het testen daarvan in goed gecontroleerd onderzoek dient daartoe wel hoog op de agenda te staan.

\section{Referenties}

1. Lorig KR, Holman HR. Self-Management Education: History, Definition, Outcomes, and Mechanisms. Annals of Behavioral Medicine 2003;26: 1-7.

2. Graves KD. Social cognitive theory and cancer patients' quality of life: A meta-analysis of psychosocial intervention components. Health Psychology 2003;22:210-219.

3. Rose C, Wallace L, Dickson R, Ayres J, Lehman R, Searle Y, Burge PS. The most effective 
psychologically-based treatments to reduce anxiety and panic in patients with chronic obstructive pulmonary disease (COPD): A systematic review. Patient Education and Counseling 2002;47:311-318.

4. Meyer TJ, Mark MM. Effects of psychosocial interventions with adult cancer patients: a meta-analysis of randomized experiments. Health Psychology 1995;14:101-108.

5. Berkman LF, Blumenthal J, Burg M, Carney RM, Catellier D, Cowan MJ, Czajkowski SM, DeBusk R, Hosking J, Jaffe A, Kaufmann PG, Mitchell P, Norman J, Powell LH, Raczynski JM, Schneiderman N. Effects of treating depression and low perceived social support on clinical events after myocardial infarction: The Enhancing Recovery in Coronary Heart Disease Patients (ENRICHD) randomized trial. JAMA 2003;289:3106-3116.

6. Denollet J, Brutsaert DL. Reducing emotional distress improves prognosis in coronary heart disease: 9-year mortality in a clinical trial of rehabilitation. Circulation 2001;104: 2018-2023.

7. Stiegelis HE, Hagedoorn M, Sanderman R, Bennenbroek FTC, Buunk BP, Van den Bergh ACM, Botke G, Ranchor AV. The impact of an informational self-management intervention on the association between control and illness uncertainty before and psychological distress after radiotherapy. Psycho-Oncology (in press).

8. Petrie KJ, Cameron L, Ellis CJ, Buick D, Weinman J. Changing illness perceptions after myocardial infarction: An early intervention randomized controlled trial. Psychosomatic Medicine 2002;64:580-586.

9. Kuijer RG, Buunk BP, de Jong GM, Ybema JF, Sanderman R. Effects of a brief intervention program for patients with cancer and their partners on feelings of inequity, relationship quality and psychological distress. Psycho-Oncology (in press).

10. Spiegel D, Bloom JR, Kraemer HC, Gottheil E. Effect of psychosocial treatment on survival of patients with metastatic breast cancer. Lancet 1989;14:888-891. 


\section{Sekse-verschillen in de relatie tussen ervaren gezondheid en sterfte}

Prof. Dr. D.J.H. Deeg

Vrije Universiteit Amsterdam

\section{Inleiding}

Het eigen oordeel over de gezondheid, oftewel de ervaren gezondheid, wordt in brede kring gezien als een goede, veelomvattende gezondheidsindicator. Deze visie wordt door veel en divers onderzoek ondersteund, met name door de predictieve waarde van de ervaren gezondheid (EG) voor toekomstige sterfte $[1,2]$.

Over de redenen waarom de EG zo'n goede voorspeller voor sterfte is, bestaat echter nog veel onduidelijkheid. Bovendien is het "bewijsmateriaal" voor de relatie EG-sterfte niet altijd even consistent. Bijvoorbeeld kunnen sommige studies de relatie alleen aantonen bij mannen [3], andere juist alleen bij vrouwen [4]. Tot voor kort werden deze verschillen genegeerd, om te kunnen benadrukken hoe sterk de relatie EG-sterfte is [2]. Maar juist verschillen tussen subgroepen van de bevolking kunnen "werkingsmechanismen" aan het licht brengen die bijdragen aan de predictieve waarde van EG voor sterfte. Als namelijk EG sterfte voorspelt in de ene, maar niet in de andere groep, dan kunnen kenmerken waarin de twee groepen zich onderscheiden worden onderzocht op hun mogelijk verklarende waarde voor de relatie EG-sterfte. Seksespecifiek onderzoek lijkt een vruchtbare benadering, vanwege beschreven verschillen tussen vrouwen en mannen in zowel subjectieve als objectief-biologische reacties, alsook in sociale omstandigheden [5].

Eén van de mogelijke verklaringen voor sekseverschillen in de relatie EGsterfte, is dat de betekenis van "gezondheid", en dus het oordeel over de eigen gezondheid, voor vrouwen en mannen kan verschillen. De veelgebruikte, enkelvoudige vraag naar de EG luidt: "Hoe is over het algemeen uw gezondheid?" Deze formulering laat open wat onder "gezondheid" moet worden verstaan, en hoe het oordeel tot stand moet komen. Bijgevolg zal de ene respondent haar/zijn gezondheid meten aan die van bekenden van dezelfde leeftijd, de andere respondent recente veranderingen in de eigen gezondheid erbij betrekken, en een derde respondent zich baseren op haar/zijn gezondheidsverwachtingen voor de toekomst. ledere respondent heeft in feite een ander "concept" van gezondheid in haar/zijn hoofd. Deze bijdrage maakt gebruik van vijf verschillende vragen over de EG, die ieder een ander concept van gezond- 
heid inhouden. Onderzocht wordt welke sekseverschillen er bestaan in de relatie tussen ieder EG-concept en toekomstige sterfte, om zodoende tot verklaringen te komen voor de predictieve waarde van EG voor sterfte.

\section{De onderzochte groep}

De gegevens zijn afkomstig van de basismeting van de Longitudinal Aging Study Amsterdam (LASA), die plaats vond in 1992-93 bij 3107 mannen en vrouwen van 55-85 jaar [6]. Naast een mondeling interview kregen de deelnemers ook een schriftelijke vragenlijst, die werd ingevuld door $74 \%$ van de oorspronkelijke deelnemers. Twee van de vijf EG-concepten vormden een onderdeel van deze vragenlijst. Het aantal deelnemers van wie volledige gegevens over alle vijf EG-concepten beschikbaar is, bedraagt 1917. De sterfte wordt regelmatig nagegaan bij de gemeentelijke bevolkingsregisters en is momenteel bekend tot 1-12000, dus over een periode van 7,5 jaar.

\section{De gegevens}

De vijf EG-concepten zullen kort worden aangeduid als "algemeen", "leeftijdsgenoten", "10 jaar geleden", "huidig" en "toekomstig". De reeds genoemde "algemene" vraag naar de EG heeft antwoordmogelijkheden $1=$ uitstekend, $\ldots 5$ = slecht. De tweede vraag betreft de gezondheid in vergelijking met leeftijdsgenoten, eveneens met vijf antwoordmogelijkheden: $1=$ veel slechter, $\ldots 5=$ veel beter. De derde vraag maakt een vergelijking met 10 jaar geleden, met dezelfde antwoordmogelijkheden. Voor huidige en toekomstige EG wordt gebruik gemaakt van de RAND Vragenlijst Algemene GezondheidsBeleving [7]. Deze lijst omvat vragen naar onder meer huidige (vier vragen, bijv. "Ik ben gezonder dan de meeste mensen die ik ken") en toekomstige EG (drie vragen, bijv. "Ik denk dat mijn gezondheid in de toekomst slechter zal worden"). ledere vraag heeft weer vijf antwoordmogelijkheden: $1=$ beslist niet waar, $\ldots .5$ beslist waar. De vier resp. drie vragen werden opgeteld tot een score van 4-20 resp. 3-15. Om de scores vergelijkbaar te maken met die van de eerste drie concepten, werden ze gedeeld door resp. 4 en 3, zodat de waarden ook tussen 1-5 vielen.

Een groot aantal andere gegevens werd in het onderzoek betrokken, omdat zij de relatie tussen EG en sterfte mede zouden kunnen verklaren. Deze betroffen sociaal-demografische kenmerken, chronische 
ziekten, lichamelijke, depressieve en cognitieve stoornissen, functionele beperkingen, hulpbehoevendheid, leefstijl, sociaal netwerk en sociale steun, sociale participatie, en persoonlijkheid [8].

\section{Resultaten}

Ook in dit onderzoek lijkt EG een goede voorspeller voor sterfte. De relatieve risico's lopen van 1,56 tot 1,10, hetgeen betekent dat iemand die een punt slechter scoort een $56 \%$ tot $10 \%$ grotere kans heeft om in 7,5 jaar te overlijden. $\mathrm{Er}$ is een duidelijk verschil tussen vrouwen en mannen: bij vrouwen zijn voor alle EG-concepten de samenhangen zwakker dan bij mannen. Ook zijn er verschillen tussen de concepten: zowel bij mannen als bij vrouwen toont het "10 jaar geleden"-concept de zwakste samenhang. Bij vrouwen is de samenhang van "toekomstige" EG met sterfte ook erg zwak. Nemen we nu tevens alle mogelijke verklarende variabelen op in de modellen, dan nemen de samenhangen tussen de EG-concepten en sterfte uiteraard af. Deze afname is bij vrouwen zó sterk, dat er geen significante samenhang met sterfte overblijft. Bij mannen blijft een samenhang over voor twee EG-concepten: "leeftijdsgenoten" en "huidige" EG. Voor beide concepten geldt dat een man die een punt slechter scoort, een ongeveer $25 \%$ grotere kans heeft om in 7,5 jaar te overlijden.

\section{Conclusies}

De grotere predictieve waarde van EG voor sterfte bij mannen in vergelijking met vrouwen blijft overeind wanneer rekening wordt gehouden met andere verklarende factoren. Dit geldt met name voor twee EG-concepten: "leeftijdsgenoten" en "huidige" EG, waarbij het sekseverschil voor "leeftijdsgenoten" het grootst was. Een gemeenschappelijk kenmerk van beide concepten is dat zij op het heden zijn gebaseerd. In een eerdere studie onder mannen bleek het "leeftijdsgenoten"-concept eveneens een goede voorspellende waarde te hebben voor sterfte [9]. We noemen hier enkele mogelijke achterliggende mechanismen. Ten eerste kan het zijn dat mannen uit de vergelijking van hun eigen gezondheid met die van hun leeftijdsgenoten accuratere informatie halen dan vrouwen. Ten tweede is het mogelijk dat mannen uit die vergelijking andere informatie halen dan vrouwen, namelijk informatie die specifieker op sterfte is gericht. Deze laatste verklaring wordt ondersteund door gegevens uit de basismeting [8]. 
De resultaten hebben relevantie voor de praktijk, want zij laten het nut zien van de ervaren gezond heid als "proxy" voor het klinisch oordeel over de gezondheid, als aanwijzing tot het doen van nadere klinische metingen, en als hulp bij het stellen van een prognose. Bij mannen zal daarbij veelal gelet moeten worden op levensbedreigende klachten, bij vrouwen op niet-levensbedreigende klachten, die echter wèl de kwaliteit van leven op de proef stellen.

\section{Referenties}

1. Idler EL, Benyamini Y. Self-rated health and mortality: A review of twenty-seven community studies. Journal of Health and Social Behavior 1997;38:21-37.

2. Benyamini Y, Idler EL. Community studies reporting association between self-rated health and mortality: Additional studies, 1995-1998. Research on Aging 1999;21:392-401.

3. Idler EL, KasI SV. Health perceptions and survival: Do global evaluations of health status really predict mortality? Journals of Gerontology: Social Sciences 1991;46:S55-65.

4. McCallum J, Shadboldt B, Wang D. Self-rated health and survival; A 7-year follow-up study of Australian elderly. American Journal of Public Health, 1994;84:1100-1105.

5. Arber S, Ginn J. Gender, class, and health in later life. In S. Arber, J. Ginn (Eds.), Gender and later life. A sociological analysis of resources and constraints (pp. 107-128). London: Sage Publications, 1991.

6. Deeg DJH, Westendorp - de Serière M. (Eds.). Autonomy and well-being in the aging population I: Report from the Longitudinal Aging Study Amsterdam 1992-1993. Amsterdam: VU Uitgeverij, 1994.

7. Kriegsman DMW, Van Eijk JTM, Deeg DJH. Psychometric properties of the RAND General Health Perception Questionnaire in the Netherlands. Tijdschrift Sociale Gezondheidszorg, 1995; 73/6:390-398.

8. Deeg DJH, Kriegsman DMW. Concepts of self-rated health: specifying the gender difference in mortality risk. The Gerontologist 2003;43:376-386.

9. Appels A, Bosma H, Grabauskas V, Gostautas A, Sturmans F. Self-rated health and mortality in a Lithuanian and a Dutch population. Social Science and Medicne 1996;42:681-689. 


\section{De lichamelijke gevolgen van depressie: te verklaren met biologie?}

Dr. B.W.J.H. Penninx

Wake Forest University, USA

\section{Depressie: een veelvoorkomend probleem}

Depressie wordt gekenmerkt door gebrek aan interesse in het dagelijks leven, sombere gevoelens, en verschillende somatische symptomen, zoals slaapproblemen, veranderde eetlust, moeheid, concentratieproblemen en rusteloosheid, die over een langere periode aanhouden. Een ernstige depressie, waarbij de meerderheid van de depressie symptomen aanwezig is, wordt in de psychiatrie een 'Major Depressive Disorder' genoemd. Een Major Depressive Disorder komt voor bij ongeveer $2 \%$ van de ouderen in de bevolking, hetgeen ook gevonden werd in de Nederlandse LASA studie gehouden onder ruim 300055 tot 85 jarigen [1].

Een tweede depressieclassificatie vormen de 'depressieve symptomen'. Mensen met depressieve symptomen hebben vaak minder ernstige depressie kenmerken, waardoor niet aan de ernstcriteria van Major Depressive Disorder wordt voldaan. Desalniettemin vormen depressieve symptomen een klinisch relevant probleem, aangezien depressieve symptomen een bedreiging vormen voor het welbevinden en lichamelijk functioneren van ouderen. Daarnaast zijn depressieve symptomen relevant vanwege de hoge prevalentie. Ongeveer 15 tot 20\% van de ouderen heeft depressieve symptomen, waarbij de prevalentie toeneemt met het ouder worden. Voor zowel Major Depressive Disorder als voor depressieve symptomen geldt dat oudere vrouwen tweemaal vaker lijden aan deze emotionele stoornissen dan oudere mannen. Emotionele problemen zijn vaak chronisch. Van de LASA respondenten die tijdens de basismeting depressieve symptomen hadden, had na 3 jaar 50.4\% deze symptomen nog steeds [2].

\section{Depressie leidt tot gezondheidsproblemen}

Niet alleen zijn emotionele problemen een gevolg van gezondheidsproblemen, diverse studies laten zien dat emotionele problemen ook de oorzaak van gezondheidsproblemen kunnen vormen. In een Amerikaanse studie vonden wij dat 65-plussers met depressieve symptomen een grotere kans hadden om lichamelijke beperkingen te ont- 
wikkelen tijdens de 6 jaar follow-up in vergelijking met niet-depressieve 65-plussers [3]. Dit verschil kon niet verklaard worden door het feit dat depressieve ouderen meer ziekten hadden, een ongezondere levensstijl hadden, of minder aan fysieke activiteit deden. Correctie voor dit soort verschillen was namelijk niet in staat om de verhoogde kans op lichamelijke beperkingen in depressieve ouderen te verklaren.

Ook wanneer het lichamelijk functioneren gemeten wordt door objectieve prestatietesten, blijkt dat depressie gepaard gaat met een grotere lichamelijke achteruitgang. In de Amerikaanse EPESE studie, werd ouderen gevraagd een drietal prestatietesten uit te voeren: een balanstest, een looptest en een test waarbij men vijf maal moest opstaan en moest gaan zitten in een stoel. Na 4 jaar hadden de ouderen met een hogere depressiescore een grotere lichamelijke achteruitgang dan ouderen met een lagere depressie score [4]. Soortgelijke bevindingen zijn bevestigd in de Nederlandse LASA studie [5]. Daarnaast blijkt uit de LASA studie dat zowel depressieve klachten als Major Depressive Disorder de kans op overlijden verhogen [6]. Een deel van dit effect werd veroorzaakt door cardiovasculaire ziekten, aangezien beiden ook de kans op sterfte aan hartziekten bleken te verhogen [7].

\section{Verklaart biologie de gezondheidseffecten van depressie?}

$\mathrm{Er}$ is een aantal mogelijke biologische mechanismen, maar het moet gezegd worden dat bewijs voor deze biologische mechanismen vaak niet bevestigd is in grootschalig onderzoek onder ouderen. Zo zijn er aanwijzingen dat depressie de hartslagvariabiliteit doet verminderen, hetgeen mogelijk predisponerend is voor fatale hartritmestoornissen. Ook wordt aangenomen dat een verhoogde stressreactie van het lichaam (de zogenaamde 'sympatho-adrenale hyperreactiviteit') bij depressieve patiënten kan bijdragen aan het ontstaan van cardiovasculaire aandoeningen. Bewijs hiervoor is met name geleverd voor Major Depressive Disorder, maar niet voor de wat minder ernstige depressieve symptomen, zoals deze vaak bij ouderen voorkomen.

Een andere biologische verandering die geassocieerd is met depressie, betreft de toename in cortisol, een hormoon dat vervolgens diverse andere 'stressreacties' in gang zet. Vooral bij ernstig depressieve personen, blijkt een verhoogde cortisol concentratie in urine en/of speekselmonsters aanwezig te zijn. Echter, de relatie tussen cortisol en mildere depressieve symptomen is minder duidelijk beschreven en zelfs inconsistent. In een recente analyse met gegevens van de InChainti study, 
vonden we geen significante relatie tussen depressive symptomen en de concentratie van cortisol in urine, verzameld over 24 uur.

Tenslotte behoeft inflammatie verdere discussie. Inflammatie is een respons van het immuunsysteem ten gevolge van verschillende stimuli dat resulteert in verhoogde niveaus van acute fase proteïnes (bijv. C-reactief proteïne (CRP)) en cytokinen (bijv. Interleukin(IL)- 6 en tumor necrosis factor (TNF)- $\alpha$ ). Deze verhoogde niveaus blijken sterke predictoren te zijn voor een gevarieerd aantal negatieve gezondheidsuitkomsten, zoals het optreden van lichamelijke beperkingen, mortaliteit, diabetes, osteoartrose symptomen, en hart- en vaatziekten. Het lijkt er dus op dat inflammatie de basis vormt van diverse pathofysiologische mechanismen die leiden tot lichamelijke beperkingen. Dit gaf aanleiding voor Ershler om IL-6 de cytokine voor gerontologen te noemen [8]. Depressie kan, als een stressor, aanleiding geven tot inflammatie en inflammatie kan via de invloed op de HPA axis weer aanleiding geven tot depressie. In de Amerikaanse Health $A B C$ studie, vonden we inderdaad dat depressie geassocieerd gaat met verhoogde niveaus van IL-6, TNF- $\alpha$ en CRP [9]. Desalniettemin blijkt dat deze inflammatoire markers niet de relatie tussen depressie en het ontstaan van lichamelijke beperkingen kunnen verklaren. In Health $A B C$ analyses, vonden we dat depressie significant de kans op lichamelijke beperkingen verhoogt $(R R=1.76,95 \% \mathrm{Cl}=1.37-$ 2.25), maar dat deze kans niet echt afneemt nadat inflammatoire markers ook in het model worden opgenomen ( $R R=1.72,95 \% \mathrm{Cl}=1.35-2.21)$.

Al met al moeten we concluderen dat er verschillende biologische mechanismen zijn aan te voeren die deels kunnen verklaren waarom depressie leidt tot een minder goede gezondheid. Echter, vooral wat betreft de mildere depressieve symptomen, is de associatie met deze biologische variabelen niet bijzonder sterk en lijken deze biologische variabelen niet compleet de link met gezondheidsuitkomsten te verklaren. Verder onderzoek is dus nodig, want vooral voor de mildere depressie, die zich vaak bij ouderen voordoet, is onderzoek naar de biologische relatie schaars.

\section{Wat verklaart nog meer de gezondheidseffecten van depressie?}

Andere verklaringen voor de ongunstige gezondheidseffecten van emotionele problemen liggen op het psychosociale en gedragsmatige terrein. Depressie is geassocieerd met een ongezondere leefstijl, zoals bijvoorbeeld roken, excessief drinken en niet lichamelijk actief zijn. Daarnaast is bekend dat depressieve ouderen over minder steun van 
hun sociale netwerk beschikken en dat doktersadviezen minder goed worden nageleefd. Een recent Amerikaans onderzoek wees uit dat depressieve ouderen kwalitatief mindere medische zorg kregen dan niet-depressieve ouderen [10]. Sociaal-gerontologisch onderzoek is nodig om verder uit te zoeken welke psychosociale mechanismen bijdragen aan de ongunstige gezondheidseffecten van depressie op oudere leeftijd.

\section{Referenties}

1. Beekman AT, Deeg DJ, van Tilburg T, Smit JH, Hooijer C, van Tilburg W: Major and minor depression in later life: a study of prevalence and risk factors. Journal of Affective Disorders 1995;36:65-75.

2. Beekman AT, Deeg DJ, Geerlings SW, Schoevers RA, Smit JH, van Tilburg W: Emergence and persistence of late life depression: a 3-year follow-up of the Longitudinal Aging Study Amsterdam. Journal of Affective Disorders 2001;65:131-138.

3. Penninx BW, Leveille S, Ferrucci L, van Eijk JT, Guralnik JM: Exploring the effect of depression on physical disability: longitudinal evidence from the established populations for epidemiologic studies of the elderly. American Journal of Public Health 1999;89:13461352.

4. Penninx BW, Deeg DJ, van Eijk JT, Beekman AT, Guralnik JM: Changes in depression and physical decline in older adults: a longitudinal perspective. Journal of Affective Disorders 2000;61:1-12.

5. Penninx BW, Beekman AT, Deeg DJ, van Tilburg W: [Effects of depression on physical health and mortality in the elderly. Longitudinal results of the LASA research]. Tijdschrift voor Gerontologie en Geriatrie 2000;31:211-218.

6. Penninx BW, Geerlings SW, Deeg DJ, van Eijk JT, van Tilburg W, Beekman AT: Minor and major depression and the risk of death in older persons. Archives of General Psychiatry 1999:56:889-895

7. Penninx BW, Beekman AT, Honig A, Deeg DJ, Schoevers RA, van Eijk JT, van Tilburg W: Depression and cardiac mortality: results from a community-based longitudinal study. Archives of General Psychiatry 2001;58:221-227.

8. Ershler WB: Interleukin-6: a cytokine for gerontologists. Journal of the American Geriatric Society 1993;41:176-181.

9. Penninx BW, Kritchevsky S, Yaffe K, Newman AB, Simonsick EM, Rubin S, Ferrucci L, Harris T, Pahor M: Inflammatory markers and depressed mood in older men and women: Results from the Health ABC study. Biological Psychiatry 2003;54:566-572.

10. Druss BG, Bradford WD, Rosenheck RA, Radford MJ, Krumholz HM: Quality of medical care and excess mortality in older patients with mental disorders. Archives of General Psychiatry 2001;58:565-572. 


\section{Chronisch zieken: ongelijke zorgen, gelijke zorg?}

Prof. Dr. G.A.M. van den Bos

AMC / Universiteit van Amsterdam, RIVM

In deze bijdrage wordt de bijdrage van het zorgonderzoek aan het vraagstuk van sociale ongelijkheid bij chronisch zieken belicht.

\section{Gezondheidswinst en gezondheidsverlies}

Problemen van de openbare gezondheidszorg hangen sterk samen met de sociale omstandigheden. Deze 'sociale kwestie' was rond de voorlaatste eeuwwisseling aanleiding te ijveren voor verbetering van de gezondheid via maatregelen buiten de gezondheidszorg, zoals op het gebied van arbeidsomstandigheden, behuizing, hygiënische omstandigheden en woonomgeving. De combinatie van sociaal-hygiënische maatregelen en verbeteringen in de gezondheidszorg heeft geleid tot een indrukwekkende gezondheidswinst voor alle groepen in de bevolking. We leven steeds langer en steeds langer in goede gezondheid.

De keerzijde van deze gezondheidswinst is het onvermijdelijk gezondheidsverlies als gevolg van chronische ziekten. Geschat wordt dat 10\% van de Nederlandse bevolking geconfronteerd wordt met chronische ziekte; hiervan heeft $20-30 \%$ te maken met de gevolgen van comorbiditeit $[1,2]$. Sociaal-demografische projecties wijzen uit dat chronische ziekten onder ouderen in de komende 20 jaar zullen toenemen met percentages tussen 25 en 60\% [3]. Daarnaast leiden de verbeteringen op het gebied van diagnostiek en behandeling onontkoombaar tot een verdere stijging - ook op jongere leeftijd. Chronische ziekte wordt steeds meer een probleem van alle leeftijden.

\section{Chronische ongelijkheid}

Niet alle groepen van de bevolking hebben gelijkelijk gedeeld in de gezondheidswinst. Verschillen in gezondheid zijn met de toenemende welvaart en sociale zekerheid een weerbarstig gegeven gebleven [4] Lagere sociaal-economisch groepen hebben niet alleen een gemiddeld kortere levensduur maar in dit kortere leven over vrijwel de gehele linie meer chronische ziekten. Ook worden zij relatief zwaarder getroffen door de consequenties van het chronisch ziek-zijn, zoals omschreven in het Kwaliteit van Leven-model of het ICF-model, voorheen ICIDH model. 
Sociale gezondheidsverschillen zijn aangetoond voor een reeks van parameters, zoals klinische ziektekenmerken, functionele gezondheid, depressie, gezondheidsperceptie, ervaren kwaliteit van leven en handicap. In dit verband kan gesproken worden van een 'double suffering', een cumulatie van gezondheidsproblemen bij dezelfde bevolkingsgroepen. Er zijn aanwijzingen dat de sociale gap tijdens het beloop van de ziekte afneemt wat betreft de functionele gezondheid, maar juist toeneemt met betrekking tot het sociaal-maatschappelijk functioneren [5,6]. Deze maatschappelijke ongelijkheid overschrijdt de grenzen van de gezondheidszorg, maar maakt daar wel deel van uit.

\section{Gelijkheid in toegang tot zorg}

Gelijkheid in gezondheid wordt doorgaans vertaald met gelijke toegang tot zorg. Gelijke toegankelijkheid van de gezondheidszorg voor alle groepen in de bevolking is - tot voor kort? - het basisprincipe van ons stelsel. In het zorgonderzoek wordt dit vraagstuk gewoonlijk bestudeerd aan de hand van het model van Andersen [7]. In dit model wordt onderscheid gemaakt naar consumptienoodzaak (de met gezondheid samen hangende zorgbehoefte), consumptiegeneigdheid (onder meer samenhangend met demografische en sociaal-psychologische kenmerken) en consumptiemogelijkheid (onder meer samenhangend met sociaal-economische status). Er is sprake van ongelijke toegang tot zorg indien andere variabelen dan 'needs' het gebruik van gezondheidszorg verklaren. Het chronisch zieken-onderzoek op dit gebied wijst uit dat over het algemeen sprake is van gelijke toegang tot zorg bij gelijke zorgbehoefte. Voor bepaalde zorgvoorzieningen blijven echter sociaal-economisch verschillen bestaan na correctie voor zorgbehoefte $[4,5,8]$. Chronisch zieken met een hoge sociaal-economische status maken relatief meer gebruik van medisch-specialistische zorg en paramedische zorg, en hebben meer kans thuiszorg te krijgen in plaats van verpleeghuiszorg. In hoeverre deze verschillen wijzen op verschillen in kwaliteit van zorg, is moeilijk vast te stellen bij afwezigheid van duidelijke indicatiestellingen. Vooralsnog is dit het geval voor de zorg voor chronisch zieken. De ontwikkeling van multidisciplinaire richtlijnen is noodzakelijk om het zorggebruik adequater af te stemmen op de zorgbehoefte. Op basis hiervan kan de kwaliteit van de chronische zorg nader worden bepaald; vervolgens kan worden vastgesteld in hoeverre bepaalde groepen suboptimale zorg ontvangen. 


\section{Gelijk is gelijk}

Gezondheidsverschillen kunnen worden versterkt doordat de gezondheidszorg en samenleving de problemen onvoldoende erkennen. De zorg voor chronisch zieken zal de gezondheidszorg in de 21e eeuw alsmede de maatschappelijke verhoudingen verder op de proef stellen. Het chronisch zieken-vraagstuk is direct verbonden aan de sociale vooruitgang van de afgelopen eeuw maar roept in essentie dezelfde vraagstukken op uit het volksgezondheidsdebat dat door de sociaal-hygiënisten werd ingezet: de vraagstukken van sociale gelijkheid, sociale rechtvaardigheid en sociale zekerheid. Waar de sociaal-hygiënisten van de oorzaken van ziekte de sociale kwestie hebben gemaakt, zo dient nu aan de gevolgen van ziekten de sociale kwestie verbonden te worden.

De niet onaanzienlijke bijdrage van het zorgonderzoek is vooral gelegen op het terrein van fysieke beperkingen, kwaliteit van leven, individuele coping-stijlen, sociaal psychologische attributen en sociale steun vanuit de directe omgeving $[9,10]$. Opmerkelijk is dat het sociaal-maatschappelijk functioneren slechts marginaal deel uitmaakt van het huidige zorgonderzoek bij chronisch zieken, terwijl belemmeringen op het gebied van maatschappelijke participatie en autonomie in de ervaringen van chronisch zieken op de voorgrond staan.

\section{Verbreding horizon zorgonderzoek}

De specifieke situatie van chronisch zieken vergt een verbreding van de horizon van het zorgonderzoek.

a. Betrek de klinische setting en de zorgpraktijk optimaal bij het onderzoek. Meer inzicht dient te komen in de samenhang tussen klinische ziektekenmerken en de consequenties voor het persoonlijk en maatschappelijk functioneren van chronisch zieken teneinde de zorgpraktijk adequaat te kunnen ondersteunen bij de afstemming van de multidisciplinaire zorg op de zorgbehoefte van chronisch zieken en de bevordering van sociale gelijkheid voor alle leeftijdsgroepen.

b. Betrek belemmeringen op het gebied van maatschappelijke participatie in de meting van de lange termijn gezondheidsuitkomsten. Zoals klinische parameters een te smalle basis vormen om het ziekte beloop te kwantificeren, zo vormen kwaliteit van leven-instrumenten een te smalle basis om de consequenties van ziekte over de volle breedte in kaart te brengen.

c. Moduleer het onderzoeksinstrumentarium voor de zorgpraktijk. 
Beschikbare onderzoeksinstrumenten zijn voor de toepassing in de praktijk vaak te lang en onvoldoende gedetailleerd.

d. Maak kennis van de zorgpraktijk, inclusief ervaringsdeskundigheid van chronisch zieken, tot onderdeel van de wetenschappelijke scholing van aio's en onderzoekers. Dergelijke expertise kan een belangrijke bijdrage leveren aan de vertaling van onderzoeksresultaten in de praktijk en vice versa.

Het zorgonderzoek is erbij gebaat als een zwenking plaatsvindt van onderzoek van de zorg naar het onderzoek in de zorg en samenleving.

\section{Referenties}

1. Heijmans MJWM, Rijken PM, Schellevis FG, van den Bos GAM. Meer dan een ziekte; de gevolgen van comorbiditeit vanuit het perspectief van chronisch zieken en gehandicapten. Amsterdam: AMC/UvA; Utrecht: Nivel, 2003.

2. Gijsen R, Hoeymans N, Schellevis FG, Ruwaard D, Satariano WA, van den Bos GAM. Causes and consequences of comorbidity: a review. Journal of Clinical Epidemiology 2001;54: 661-674.

3. Van Oers JAM (red). Gezondheid op koers? Volksgezondheid Toekomst Verkenning 2002. Houten: Bohn Stafleu Van Loghum, 2002.

4. Stronks K, Hulshof J (red). De kloof verkleinen; theorie en praktijk van de strijd tegen sociaal-economische gezondheidsverschillen. Assen: Van Gorcum, 2001.

5. Jacobi CE, Mol GD, Boshuizen HC, Rupp I, Dinant HJ, van den Bos GAM. Impact of socioeconomic status on the course of rheumatoid arthritis and on related use of health care services. Arthritis and Rheumatism (Arthritis Care \& Research) 2003;49:567-573.

6. Van den Bos GAM, Smits JPJM, Westert GP, van Straten A. Socioeconomic variations in the course of stroke: unequal health outcomes, equal care? Journal of Epidemiology and Community Health 2002;56:943-948.

7. Andersen RM. Revisiting the behavioural model and access to medical care: does it matter? Journal of Health and Social Behavior 1995;36:1-10.

8. Van der Meer JBW, van den Bos J, Mackenbach JP. Socioeconomic differences in the utilization of health services in a Dutch population: the contribution of health status. Health Policy 1996;37;1-8.

9. Sprangers MA , de Regt EB, Andries F, van Agt HM, Bijl RV, de Boer JB, Foets M, Hoeymans $\mathrm{N}$, Jacobs AE, Kempen GI, Miedema HS, Tijhuis MA, de Haes HC. Which chronic conditions are associated with better or poorer quality of life? Journal of Clinical Epidemiology 2000;53:895-907.

10. Knol HR, Haken L, Kempen Gl. Disablement process and the utilization of home care among non-institutionalized elderly people: contrasting results between cross-sectional and panel data. Disability and Rehabilitation 2003;25:845-855. 


\title{
Over de auteurs
}

\author{
Prof. Dr. G.I.J.M. Kempen
}

Ruud Kempen studeerde medische en gezinssociologie aan de Rijksuniversiteit Groningen, waar hij ook zijn proefschrift met de titel Thuiszorg voor ouderen voorbereidde en verdedigde (1990). Tot 1998 was hij werkzaam bij het Noordelijk Centrum voor Gezondheidsvraagstukken van de Rijksuniversiteit Groningen, respectievelijk als senior onderzoeker en als universitair docent; hij was tevens medecoördinator van de Groningen Longitudinal Aging Study die in het kader van het landelijke onderzoeksprogramma NESTOR werd uitgevoerd. Vanaf 1998 is hij als universitair hoofddocent verbonden aan de Universiteit Maastricht. Op 1 december 2002 werd hij daar benoemd tot bijzonder hoogleraar Sociale Gerontologie bij de Capaciteitsgroep Zorgwetenschappen, sectie Medische Sociologie van de Faculteit der Gezondheidswetenschappen. Zijn onderzoek concentreert zich op de rol die psychosociale factoren spelen bij dagelijks functioneren en kwaliteit van leven van zelfstandig wonende ouderen. Hij is (mede)auteur van een groot aantal wetenschappelijke publicaties op dit gebied. Kennis op dit terrein uit epidemiologische studies wordt thans gebruikt voor de ontwikkeling en evaluatie van psychosociale interventies (met name op het terrein van zelfmanagement) ter verbetering van kwaliteit van leven en het dagelijks functioneren. Zijn onderzoek is ondergebracht bij de divisie Autonomy and Participation van het Care and Public Health Research Institute (CAPHRI) van de Universiteit Maastricht. Daarnaast is hij programmaleider van de studierichting Zorgwetenschappen aan de Universiteit Maastricht.

\section{Prof. Dr. R. Sanderman}

Robbert Sanderman is hoogleraar gezondheidspsychologie en hoofd van de sectie Health Psychology van de Disciplinegroep Gezondheidswetenschappen van de Medische Faculteit RU Groningen. Hij is tevens wetenschappelijk directeur van het Noordelijk Centrum voor Gezondheidsvraagstukken en coördineert het onderwijs op het terrein van de psychologie in het medisch curriculum. Hij studeerde in Groningen Klinische Psychologie en promoveerde daar in 1988 op een proefschrift over stress, kwetsbaarheid en distress. Bestuurlijk is hij onder meer actief als voorzitter van de Nederlandse Vereniging voor 
Psychosociale Oncologie, voorzitter van de Nederlands Behavioral Medicine Federatie en als vice-voorzitter van de onderzoeksschool Psychology en Health. In het onderzoek gaat zijn aandacht uit naar adaptatie aan chronische somatische aandoeningen. Concepten die daarin centraal staan zijn onder meer: sociale steun en intieme relatie aspecten, genderverschillen, persoonlijkheidseigenschappen, (cognitieve) adaptatie mechanismen en kwaliteit van leven. Naast onderzoek waarin patiënten vaak over vele jaren gevolgd worden, wordt door de onderzoeksgroep van de sectie Health Psychology effect onderzoek verricht naar interventies.

Prof. Dr. D.J.H. Deeg

Dorly Deeg is verbonden aan de Vrije Universiteit waar zij sinds 1991 de Longitudinal Aging Study Amsterdam (LASA) leidt, een interdisciplinair onderzoek naar veranderingen in het lichamelijk, emotioneel, cognitief en sociaal functioneren van ouderen. LASA is een samenwerkingsproject van het VU Medisch Centrum en de faculteit Sociale Wetenschappen, en wordt financieel gesteund onder meer door het Ministerie van VWS. Sinds 2001 is Dorly Deeg strategisch hoogleraar Epidemiologie van de veroudering. Haar onderzoeksactiviteiten richten zich op veranderingen in het dagelijks functioneren van ouderen, hun beleving daarvan, en op determinanten van zowel functioneren als beleving. Ook heeft de toepassing van longitudinale onderzoeksmethoden haar belangstelling.

\section{Dr. B.W.J.H. Penninx}

Brenda Penninx studeerde gezondheidswetenschappen aan de Katholieke Universiteit Nijmegen. In augustus 1992 studeerde zij af als epidemioloog en begon aan haar promotieonderzoek bij het EMGOinstituut aan de Vrije Universiteit. Ze hield zich daar binnen het LASA onderzoek bezig met de gezondheidseffecten van sociale steun bij chronisch zieken ouderen. Na haar promotie in 1996 werkte ze ruim een jaar bij het National Institute on Aging in Bethesda, USA. In 1998 en 1999 was ze opnieuw verbonden aan de Vrije Universiteit en het LASA onderzoek. Sinds 2000 werkt ze als Associate Professor (UHD) bij het Sticht Center on Aging, Wake Forest University, Winston-Salem NC, USA. Haar belangrijkste onderzoeksgebied: psychologische en biologische determinanten van het lichamelijk functioneren bij ouderen. Dr. Penninx is (co)auteur van meer dan 80 wetenschappelijke publicaties. 
Prof. Dr. G.A.M. van den Bos

Het chronisch zieken-onderzoek behoort tot het kerngebied van Trudi van den Bos, hoogleraar Sociale Geneeskunde aan het AMC/UvA. Daarbij gaat de aandacht uit naar vraagstukken op het gebied van de sociale epidemiologie, kwaliteit van leven en kwaliteit van zorg. Het onderzoek wordt uitgevoerd onder de algemene populatie, met name de oudere bevolking, en onderscheiden zorgcategorieën, met name revalidanten, alsmede onder specifieke patiëntenpopulaties, in het bijzonder CVA, kanker, reumatoïde artritis, longaandoeningen en neurologische aandoeningen. Vanuit haar expertisevelden is zij betrokken bij diverse besturen en commissies, onder andere de ZonMw-Programma-commissies Chronisch Zieken. 
